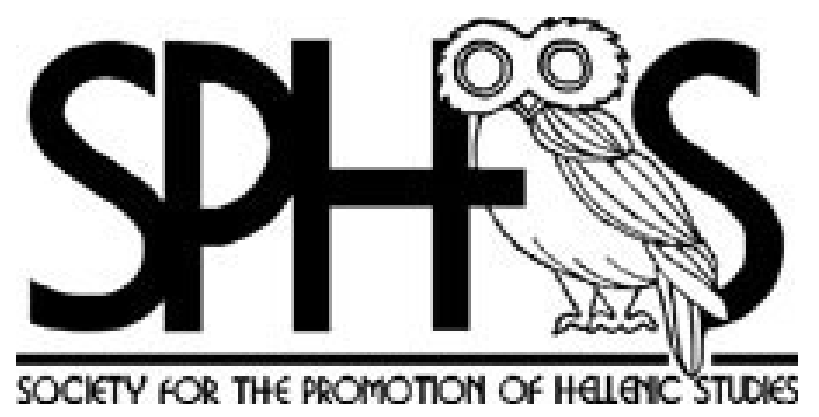

Parchments of the Parthian Period from Avroman in Kurdistan Author(s): Ellis H. Minns

Source: The Journal of Hellenic Studies, Vol. 35 (1915), pp. 22-65

Published by: The Society for the Promotion of Hellenic Studies

Stable URL: http://www.jstor.org/stable/624522

Accessed: 02/05/2014 15:27

Your use of the JSTOR archive indicates your acceptance of the Terms \& Conditions of Use, available at http://www.jstor.org/page/info/about/policies/terms.jsp

JSTOR is a not-for-profit service that helps scholars, researchers, and students discover, use, and build upon a wide range of content in a trusted digital archive. We use information technology and tools to increase productivity and facilitate new forms of scholarship. For more information about JSTOR, please contact support@jstor.org. 


\title{
PARCHMENTS OF THE PARTHIAN PERIOD FROM AVROMAN IN KURDISTAN.
}

\author{
[Plates I.-III.]
}

Avroman is a town in Persian Kurdistan lying close to the Turkish frontier between the sources of the Lesser Zab and the course of the Diala River some distance to the north of the highway from Bagdad (say Ctesiphon) to Hamadán (Ecbatana). Near it in a cave in the mountain called Kuh-i-Sálán, a peasant found about the year 1909 a stone jar hermetically sealed; in it were decayed millet seeds ${ }^{1}$ and several documents. These passed from hand to hand and some were lost, only three have survived; two, which being Greek most nearly concern us, are almost perfect, they have only suffered a certain amount from wear and from the gnawing of mice; the third written in an Aramaic script which has not yet been deciphered is said to have been much larger when found; what is left has been a good deal torn and is patched with modern leather.

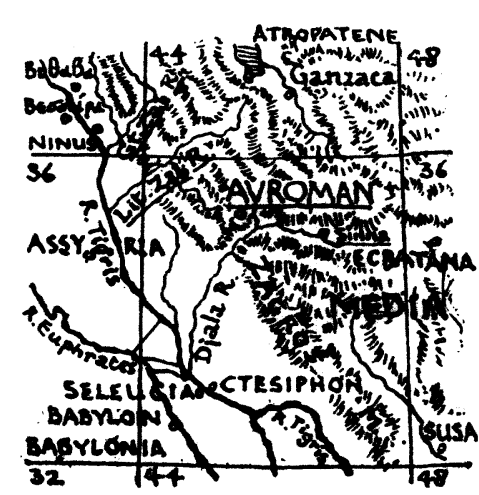

SKETCH MaP.

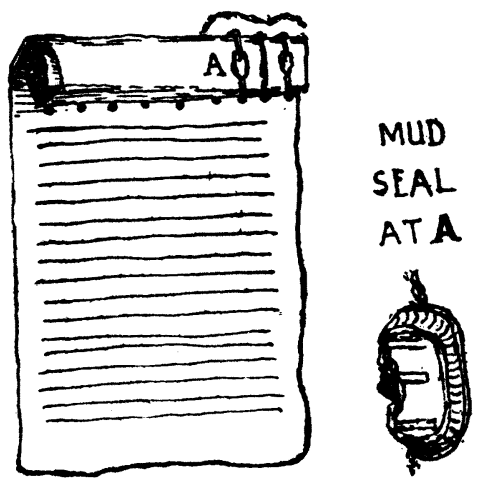

DiAgRAM OF II. BEFORE COMPLETE UNROLLING.

Mirza Sa íd Khán, an English-trained doctor at Sinna, the largest town in the neighbourhood, heard of the find and recognised that it was probably of historical importance. He made great efforts, even at the risk of his life, to secure the documents, and finally succeeded, although their possessors, in spite of the careless way in which they had kept them, were not at.all inclined to part with them.

1 It is curious that Theophrastus, Hist. Plant. VIII. xi. 6, remarks that millet keeps particularly well in Media. 


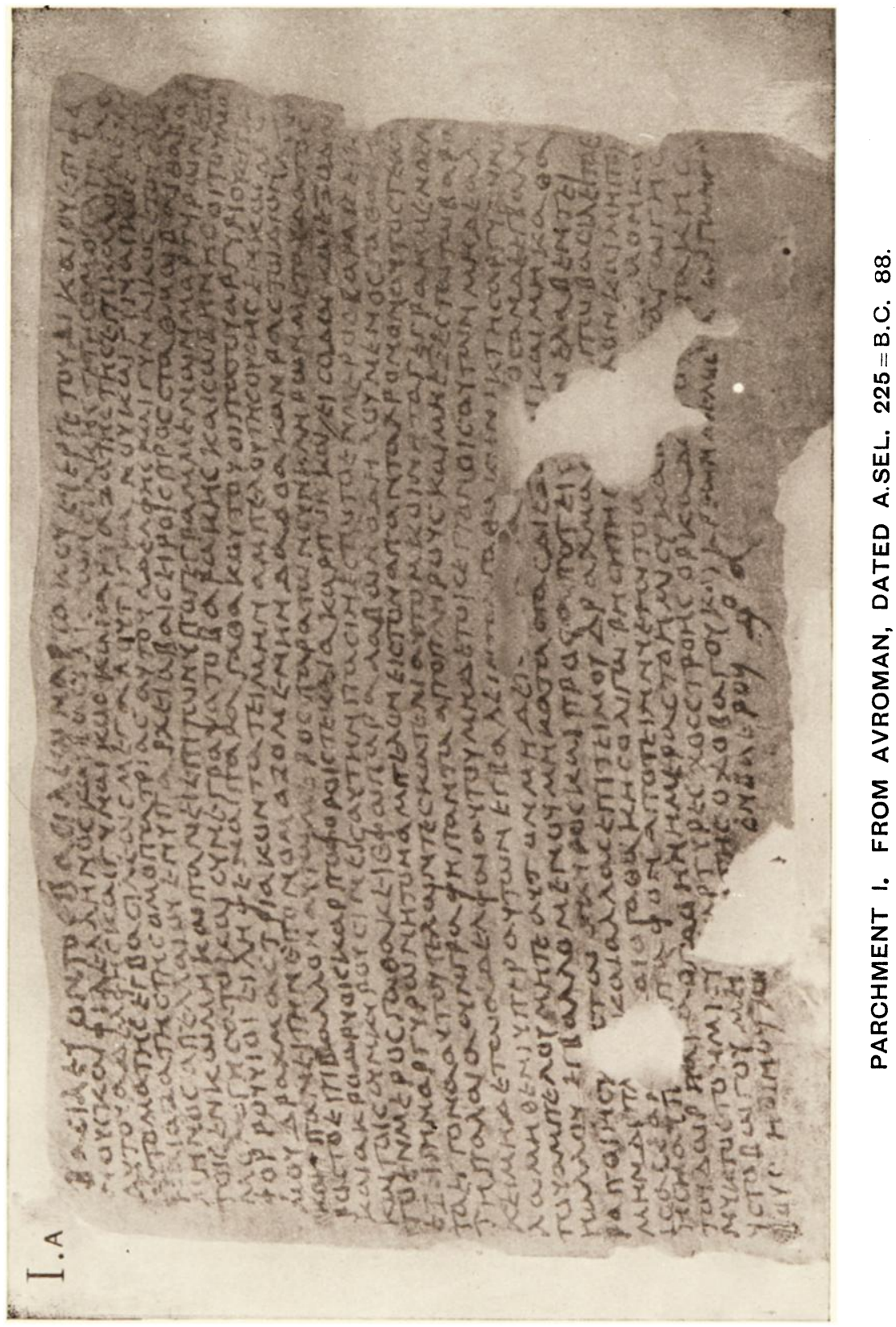




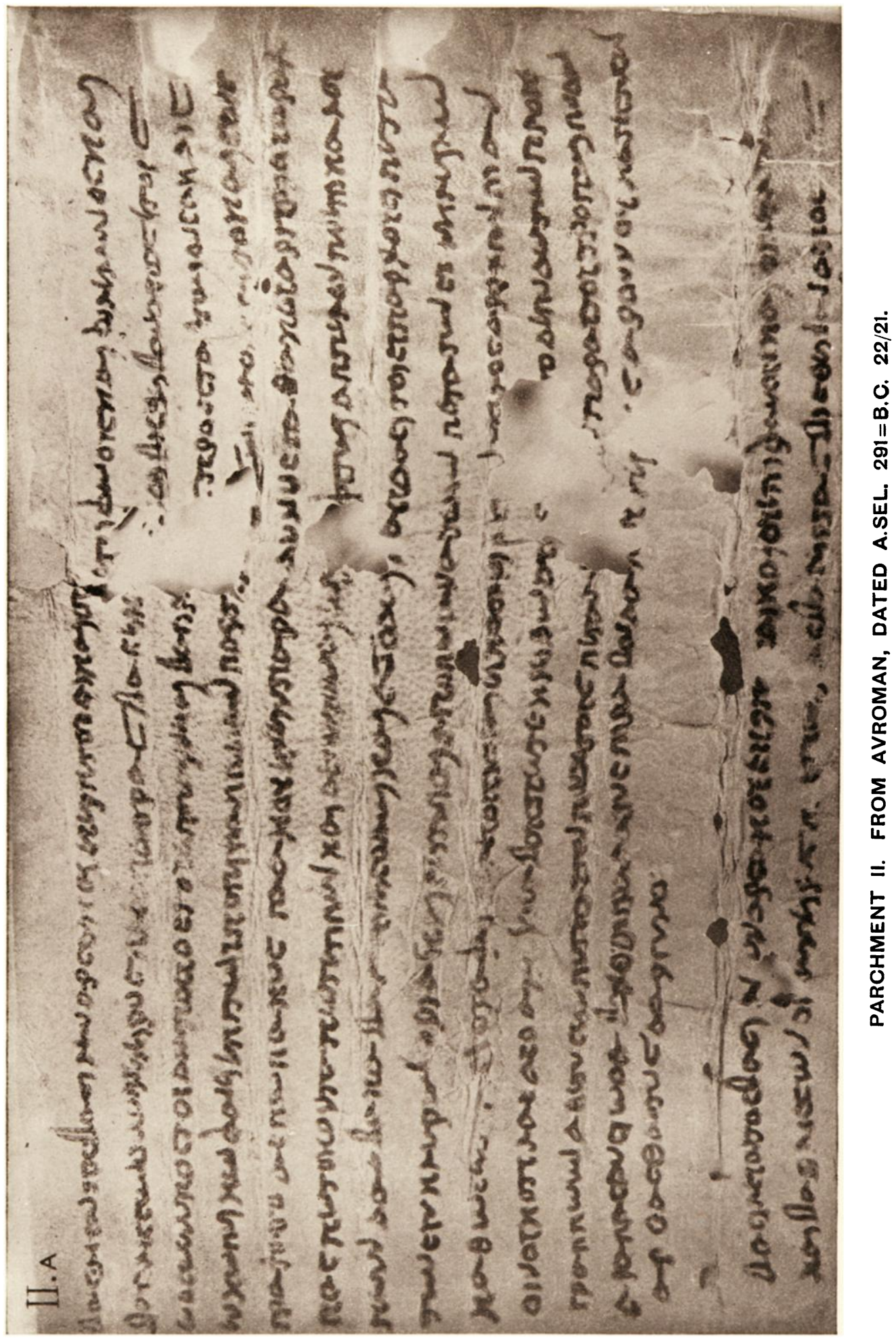


J. H. S. VOL. $X X X V$. (1915). PL. III.

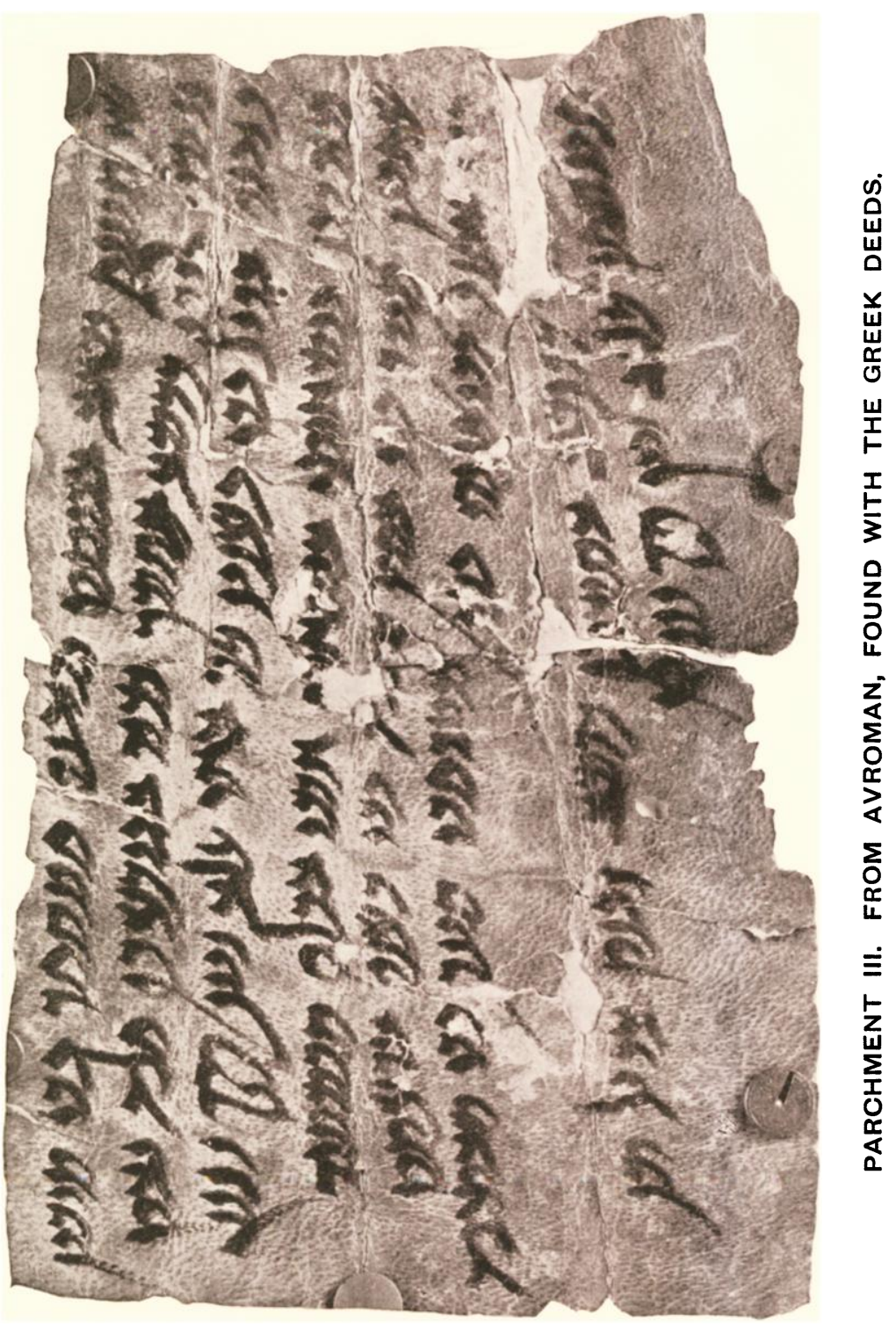


Dr. Saíd Khán came to England in October, 1913, to renew his professional knowledge and to obtain a fresh supply of medical stores. On his arrival he sent the parchments to my colleague Professor E. G. Browne, who entrusted them to me and I made a preliminary communication about them to the Society on November 11. Since then Dr. Sa íd Khán's friends adopted the view that he was not justified in depriving his philanthropic work of the aid which it might receive from the price that so great a rarity as this find might fetch, but as long as he had control he kindly reserved to me the right of publication. The documents were sold at Sotheby's, but happily they have found a home in the British Museum. I am most grateful to its authorities for letting me carry out my project of publishing them in this Journal.

\section{DESCRIPTION.}

The two perfect documents are irregular rectangles, the height being greater than the breadth: No. I. measures about $5 \cdot 6 \times 9.5$ in. $(14 \times 24 \mathrm{~cm}$.), No. II., $8 \times 10 \frac{1}{2}$ in. $(21 \times 27 \mathrm{~cm}$.). Each contains two texts (A and B, more or less duplicates, see below) and by this their shape is conditioned. Only the upper text of each document has been reproduced, very slightly less than natural size, for the purposes of this article. The whole documents are to be published in the best possible facsimile in the 1915 part of the New Palaeographical Society. No. III. now measures $6 \times 3 \frac{3}{4}$ in. $(15 \times 9.5 \mathrm{~cm}$.). If it is the lower of a pair of duplicates the original sheet must have been $6 \times 7 \frac{1}{2}$ in., very much the proportion of II. The wide margin below looks like the original bottom; that above is wider than the normal space between the lines and has no tails coming down into it, so that the cutting was made along some kind of gap in the text.

On the back of I. there are 5 lines of writing in the same alphabet as III. but a little more upright ( $v$. Table II. Col. IV.): it is the same way up as the Greek and behind the upper part of I. A. Two more lines run parallel to these, but the other way up at the back of I. B, about $3 \mathrm{in} .(7 \cdot 5 \mathrm{~cm}$.) from the bottom. A transverse endorsement runs upwards about $1 \frac{1}{4}$ in. (3 cm.) from the edge on the left as you look at the back. These endorsements ought to contain the same proper-names as the Greek and to render the riddle of the alphabet soluble, but they are too much rubbed to be any use except to shew that the third document is not entirely separate from I. and II.

When they reached my hands documents I. and III. had been completely unrolled, though I. still shewed the folds into which it had been pressed. No. II. was as the diagram shews it, the lower half unrolled, the upper undone on the left side, but still tightly rolled up and held by string on the right side. The string could not be removed without cutting it or breaking two mud seals, of which one had lost all its surface; upon the other, though it was much disintegrated, there could still be distinguished a device something like an E within a border of lines. Before proceeding to open it I had the document photographed. Assuming that a perfect record of its 
original appearance had thus been secured, I cut the string and unrolled the upper portion. As a matter of fact the negative had been unsuccessful and the operator, who had never failed me before, had omitted to inform me at once. Still the diagram gives the arrangement in all essentials.

The material of all three documents is parchment, or perhaps leather, now dark yellow or brown; it is not very well prepared; the writing has had to avoid certain rough places in the skin and the hair has not been perfectly removed. From time immemorial $\delta \iota \phi \theta$ épa material. We hear of them in Ionia, among the Jews and among the Persians. Worse than the burning of Persepolis by the accursed Alexander the Roman was the fact that in it perished the precious works of Zoroaster, written in golden ink upon prepared cowskins. Ma Twan-lin and the other Chinese authorities mention that the inhabitants of 'An-si (Parthia) write horizontally upon skins. ${ }^{2}$

In view of this general use of skins for writing it is remarkable that so few have survived from early times: Professor Flinders Petrie tells me of a leather roll dating from the twelfth Egyptian dynasty, now in Berlin; and there is an Aramaic document on leather from Elephantine. ${ }^{2 a}$ Otherwise the earliest written parchments found hitherto are the well-known pages of Demosthenes, ${ }^{3}$ and of the Cretes of Euripides, ${ }^{4}$ both referred to the second century A.D., but I do not know whether Turkistan has yielded anything older.

Documents I. and II. are each in duplicate. The top or A version was in each case rolled up tightly and bound round and round with string passed through the holes in the blank space between the two versions. These holes can be clearly seen on the facsimile of II. A ; on the facsimile of I. only two or three shew as the mice have eaten so much away just along this line. The seals of the parties and witnesses were then affixed in token that the 'close' version A (if I may so call it) agreed with the 'patent' or B version. The latter remained always accessible, but in case of doubt the string could be cut in the presence of proper authority and the 'close' version opened to prove or disprove any suspected tampering with the 'patent' version.

This matter of the 'close' and 'patent' versions can best be taken in connexion with the general form in which the documents are drawn up. It may be mentioned here that in the case of $I$. the device has failed to prevent fraud, or else a change has been made by consent without the parties troubling to indicate it in both versions: for whereas the sum named in the close version A is thirty drachmas, in the patent version $B$ thirty was written but altered to forty. The alteration is so obvious that it can hardly have been meant to deceive anyone. Other differences may be discussed later when we come to the purport of the documents.

\footnotetext{
2 A. Rémusat in Nouv. Mél. Asiat. i. p. 218.

2a E. Sachau, Aramäische Papyrus u. Ostraka aus..... Elephantine, P. xxviii. P. 13443, c. 500 B. C.

3 British Museum, Add. MS. 34473(1) ; New
}

\footnotetext{
Palaeographical Soc. i. 2.

4 Berlin P. 13217 : Berliner Klassikertexte v. 2, p. 73 sqq. ; W. Schubart, Pap. Gr. Berol.
} $30 a ;{ }^{\circ}$ New Pal. Soc. ii. 28. 
The actual hands are of very great palaeographical interest in view of the extreme rarity of non-Egyptian Greek writing other than formal inscriptions. ${ }^{5}$ Though the few specimens we possess fit fairly well into the series of Egyptian documents they generally have something unusual about them, but as they come from different parts of the Greek world there is no characteristic that ihey have in common. So our documents are neither of them quite like Egyptian writing. As far as place goes they ought to be nearest to the pieces from Seleucia in Pieria ${ }^{5 a}$ or Myra in Lycia,${ }^{6}$ but both these belong to the end of the second century A.D., so no comparison is possible. In regard to date the first century B.C. is not very well represented even in Egypt, but the Herculanean Papyri are generally referred to it and it is among these that, as Sir Frederic Kenyon has pointed out, at any rate $\mathrm{I}$. finds its closest analogues (see Table I.).

For, indeed, the writing of the most part of $I$. is rather to be classed with book-hands than with cursives, as the letters are very little run together and are fairly carefully, though not elegantly, formed. Among the Tables of Alphabets given by Sir Edward Maunde Thompson ${ }^{7}$ and Professor Gardthausen, 8 it comes closest to those taken from Volumina Herculanensia, and still closer to the alphabet of P. Nap. 1429 as given in Hayter's plates. ${ }^{9}$ Dr. Hunt has pointed out to me that P. Oxy. 236a, ${ }^{10}$ dated 64 B.C., offers decided resemblances, especially as regards the peculiar $\epsilon$ with the top turned back and a sharp angle below, but on the whole the Egyptian piece is a good deal more cursive: in $I$. $\Pi^{-}$with a detached stroke to the right is distinctly Ptolemaic,11 'but the rounded $a$, which Kenyon calls a test letter, is rather Roman' and so is the $\xi$. The retention of an epigraphic $\Sigma$ for the numeral occurs in the Flinders Petrie Papyri. ${ }^{12}$ The hand which wrote the line after the witnesses' names in I. A, with perhaps the corresponding part in I. B, and which altered thirty to forty in B, is much less careful and differs enough to deserve a separate column in the table of alphabets, but $I$ am inclined to think that the two hands are really one. It is curious that

\footnotetext{
5 The changes in the letters used on Parthian coins seem due mostly to unintelligent copying by a series of engravers rather than to the development of Greek writing as practically used in Parthian lands; see J. de Morgan, Rev. Arch. 1912, pp. 1-31, 'Etude sur la décadence de l'écriture grecque sous la dynastie des Arsacides'; but one or two details recall our documents. See also W. Wroth, Catalogue of Greek Coins in the British Museum : Parthia, 1903.

5a Palaeogr. Soc. ii. 184, date.

6 P. Lond. (Brit. Mus.), iii. 1178, Pl. XL., 1. 66 sqq. ; cf. Mitteis-Wilcken, Grundzüge und Chrestomathie der Papyruskunde, I. ii. p. 184.

7 Introd. to Gr. and Latin Palaeogr. (1912), p. 142 (No. 2).

${ }^{8}$ Gr. Palaeogr. ${ }^{2}$ Taf. I. Nos. 10, 11.

9 Thirty-six Engravings of Texts and Alpha-
}

bets from the Herculanean Fragments, Oxford, 1891, No. 3, Demetrii, in Aporias Polyacni; cf. Photographs of Facsimiles... in the Bodleian Library, published by the Oxford Philological Society, 1889, vol. vi. No. 1243. This shows the rounded $\alpha$, but Kenyon ("The Palaeogr. of the Herc. Pap.,' Festschr. Th. Gomperz dargebr. p. 376) seems to deny that this occurs at Herculaneum.

10 Oxyrhynchus Pap. ii. p. 140, Pl. V. (p. 33).

11 Something like it appears on a tetradrachm of Phrahates IV., B.M.C. Parthia, Pl. XVIII. 16.

12 P. Petr., ii. introd., p. 39, No. IV. 11 [p. 14], Pl. IV. a, ll. 4, 7, c. 255 в.c. ; cf. F. W. G. Foat, J.H.S. xxii. p. 145 : also P. Hib. i. 66 , 1. 1, Camb. Univ. Lib. Add. MS. 4465. 


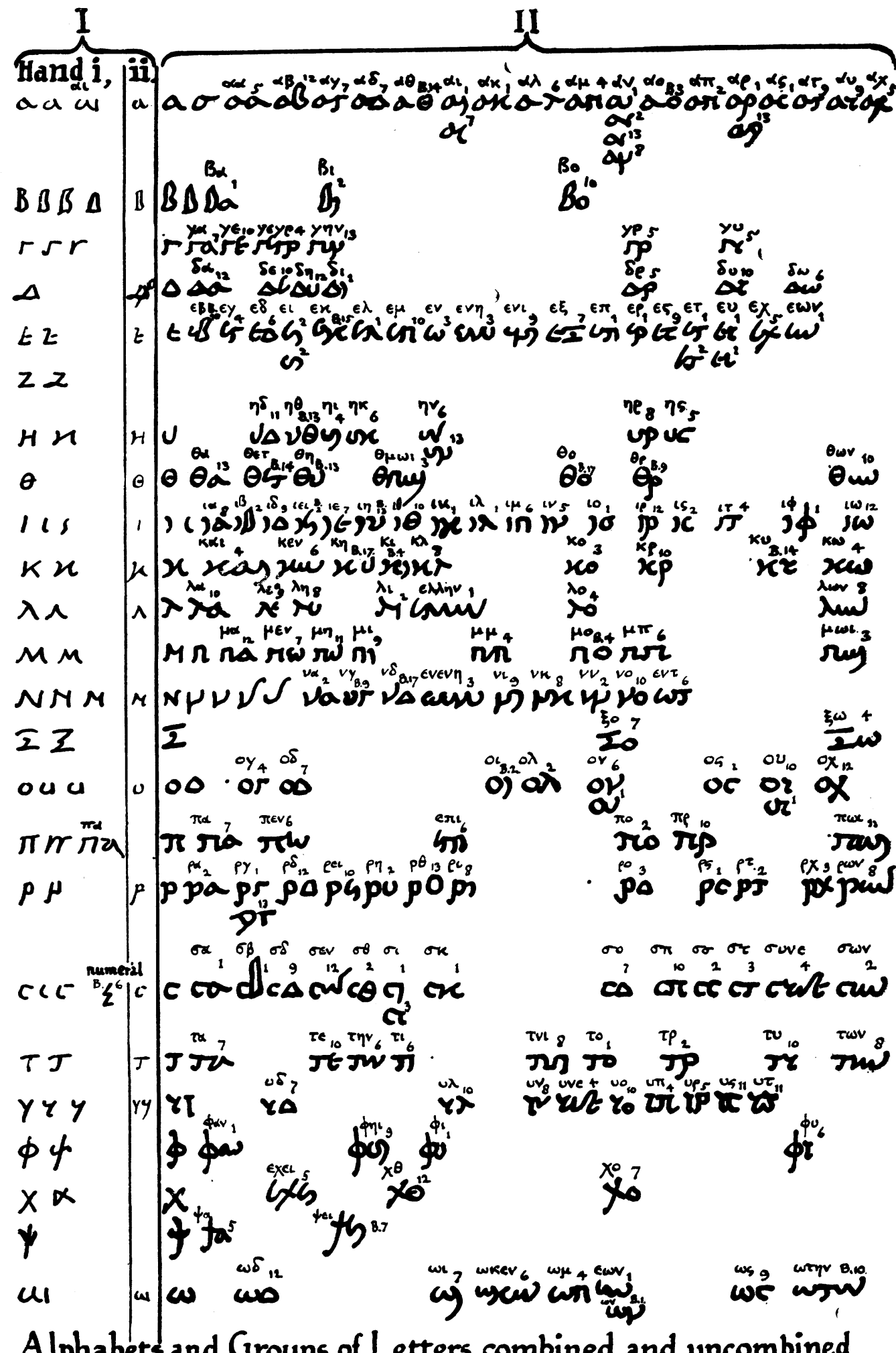

Alphabets and Groups of Letters, combined and uncombined. 
the carefully written I. leaves out $\iota$ adscript while the later and more careless II. puts it in.

Of II. Dr. Hunt writes that 'it has more archaic characteristics, which is singular as it is a couple of generations later. The tall $\nu$ is thoroughly Ptolemaic, also the very shallow $\mu .^{13}$ The man writes $-\omega \nu$ (and $-a \nu$ in

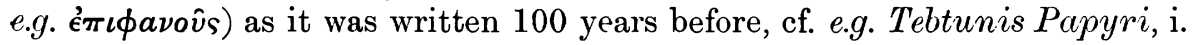
Pll. III. and VII. The $\eta$ is very remarkable, being merely in the form of a half circle. I do not remember having met this before; it is developed out of $\mu$ which is again a good Ptolemaic form and which he sometimes writes properly, e.g. in $\kappa \lambda \eta \rho \omega \nu$, l. 8 (twice), but mostly the second curve is slurred over; $\epsilon$ too is often very negligent. The linking of the $\nu$ in reıtvia, A 8 , is another characteristically early touch, cf. e.g. Tebtunis, i. Pl. III. 1. 10.' The Tebtunis papyri mentioned are dated 118 and 113 B.c. ${ }^{14}$

And yet the whole effect is not at all Ptolemaic and on trying to find analogues for the ligatures exhibited in the table, I have been singularly unsuccessful. The method of joining the letters is quite unlike the line along the top which links even such a letter as $\iota$ on to the following in many Ptolemaic hands. The table shows how $\beta, \delta, \theta, \iota, \rho, v$ and $\phi$ were incapable of really joining on to the letter following, exceptions are $\theta \eta, \theta \mu, \rho \omega$ and $v \nu$ : in general, letters only join when they fit together without the need of a connecting line. But on the other hand $\epsilon$ makes an astonishing series of ligatures with almost every letter and $a, \eta, \lambda, \nu, \sigma$ and $\tau$ are almost as adaptable. Some of the shapes recall forms which we do not meet in Egypt until the Byzantine period, e.g. $\epsilon$ with no cross stroke in ligature and especially the $\nu$. This latter only once occurs in the complete form, elsewhere it is either $\nu$ or $r$; it recalls the Ptolemaic in the way its last limb sticks up, but in both forms the first limb is quite different. The $\eta$ is like no $\eta$ that ever I saw. The final impression left upon me after trying to find any similar hand among the facsimiles accessible to me is that we have here a representative, very probably degraded, of an independent branch of Greek cursive, and it is not quite inconceivable that in some ways it is nearer to the ancestor of the vellum minuscule than is the GraecoEgyptian cursive. So much for the outer form of the documents.

In the following texts mistakes and misspellings of the scribes have not been eliminated or corrections suggested, because such corrections could not have claimed certainty: I have however supplied letters omitted by the scribe of II. in three cases. The translations aim at reproducing the confusions of the original instead of forcing a particular rectification of them: the comment on p. 51 attempts to make something of the resulting nonsense. When we were going through the documents together Professor Burkitt and Mr. Bell contributed readings that I cannot now identify.

${ }^{13} M$ is sometimes $\Pi$ on Parthian coins, e.g. Phrahates III. B.M.C. Parthia, Pl. XI. 1.

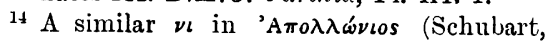

Pap. Gr. Berol. $8 c, 104$ B.c.). This and $i b$. $8 d$ show the nearest approach to our $\eta$ that I have met. 
I.

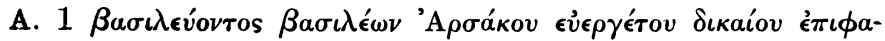

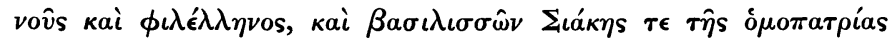

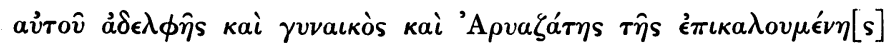

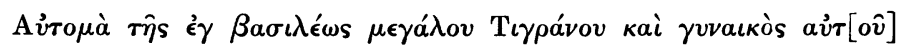

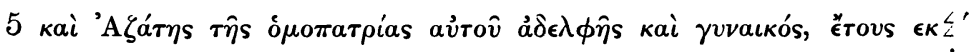

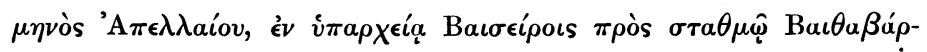

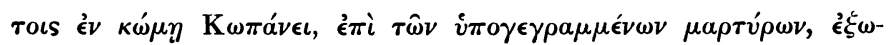


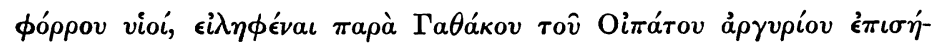

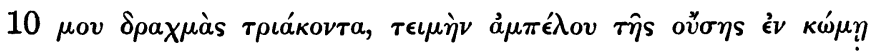

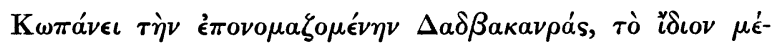

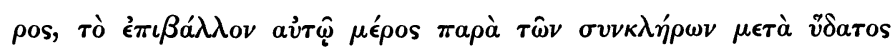

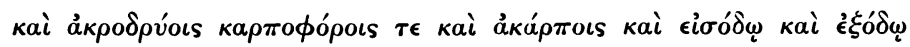

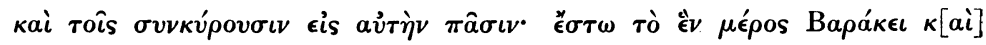

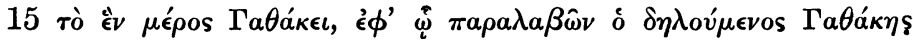

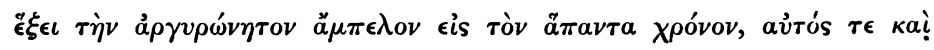

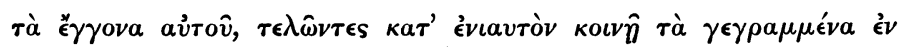

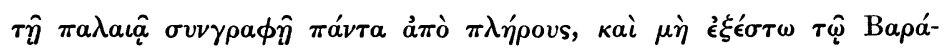

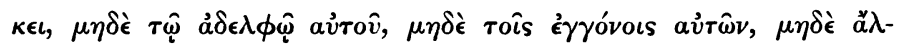

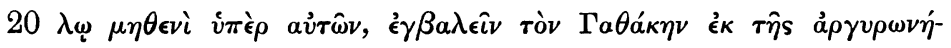

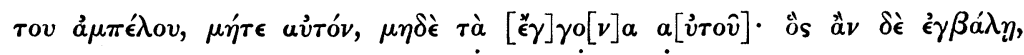

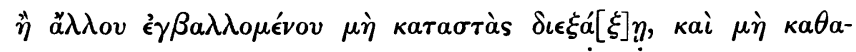
$\rho \grave{a} \pi o \iota \dot{\eta} \sigma \eta \eta \eta$

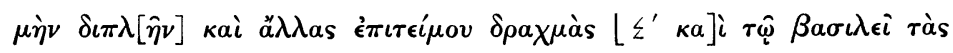

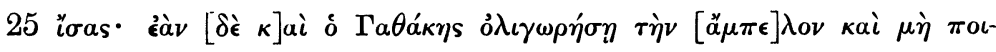

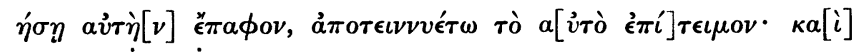

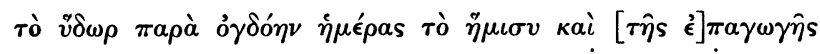

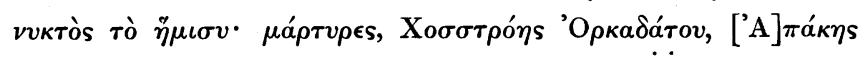

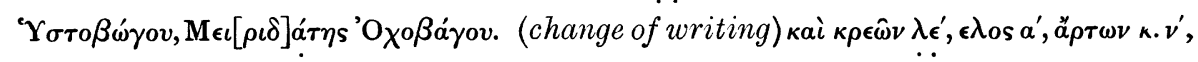

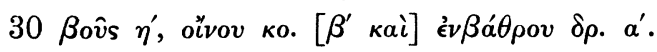

27, кa! Hunt, pointing out that ‘ does turn

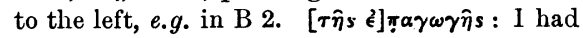
thought of $[\kappa a] \tau a \gamma \omega \gamma \hat{\eta} s$, but a break in the horizontal line of the crucial letter does not seem to come in a $\tau$. Bell doubts the mark after кai suiting the $\tau$ of $\tau \hat{\eta} s$, and thinks the break in $\pi$ may be due to flaking off, but I am still unconvinced.

29, $\kappa \rho \epsilon \hat{\omega} \nu \lambda \epsilon^{\prime}$. Bell, perhaps $\lambda(i \tau \rho a \iota) \epsilon^{\prime}$. $\epsilon \lambda o s$, Hunt, é̀âs. $a^{\prime}$, Bell, $\lambda^{\prime}$. 


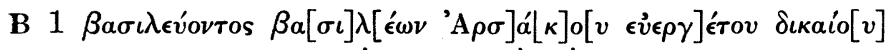

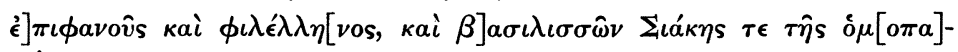

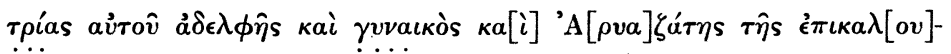

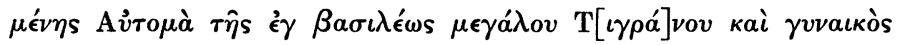

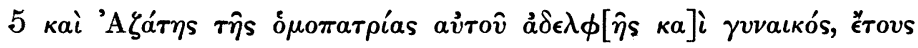

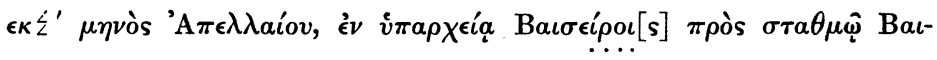

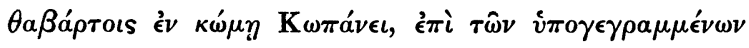

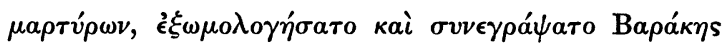

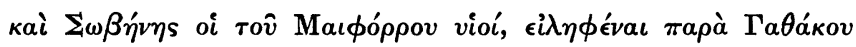

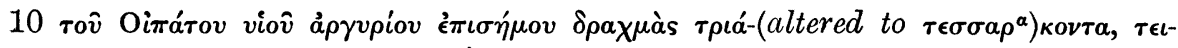

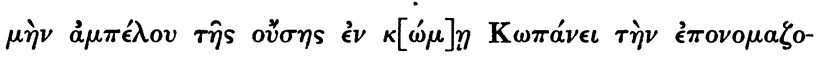

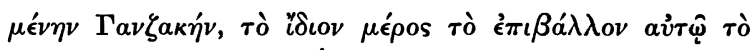

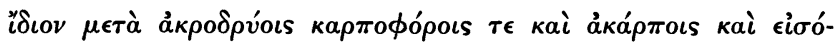

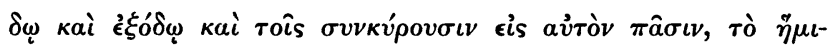

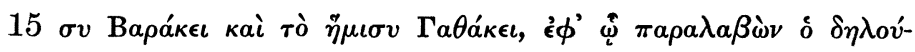

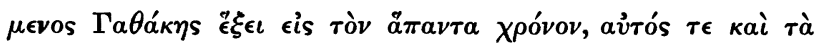

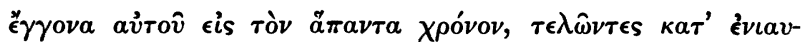

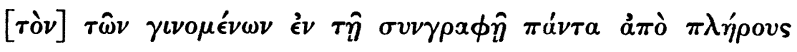

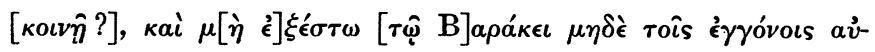

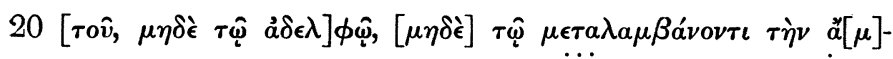

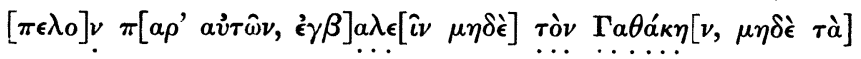

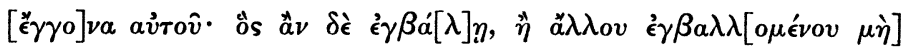

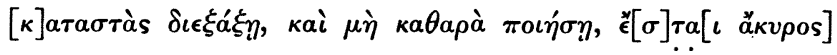

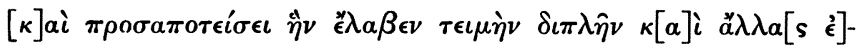

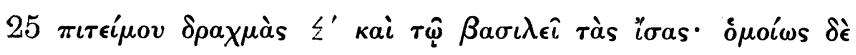

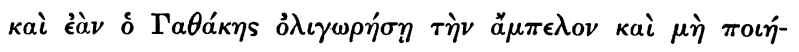

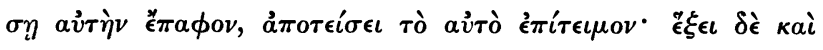

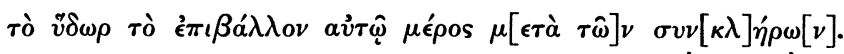

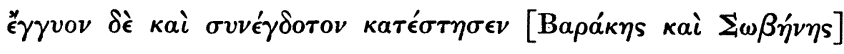

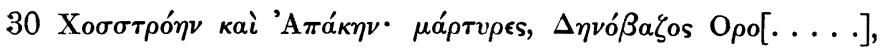

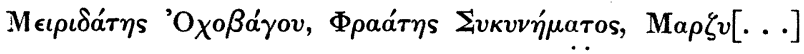

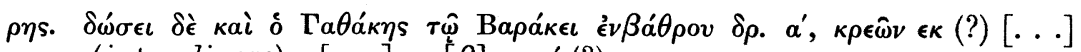
(inter lineas) $\kappa[\ldots] \kappa \epsilon,[\beta]$ oṿ $\dot{\eta}(?)$

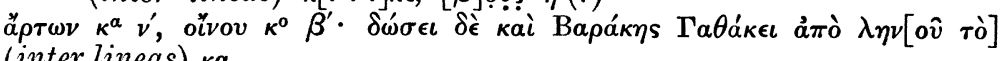
(inter lineas) $\kappa \alpha$

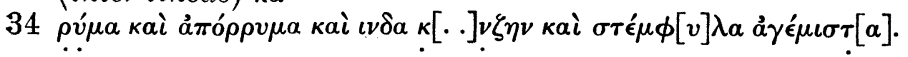

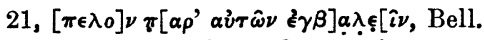

$32, \kappa \rho \in \hat{\omega} \nu$ єк (?), Bell.

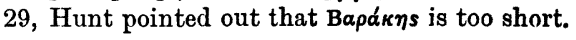

$34, \kappa \alpha$ may be $\varsigma^{\prime} \alpha . \quad \kappa[\ldots] \nu \zeta \eta \nu$, Hunt. 
II.

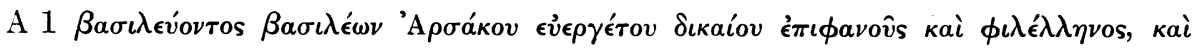

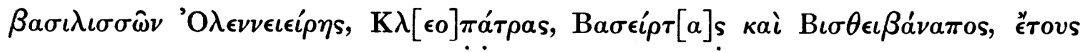

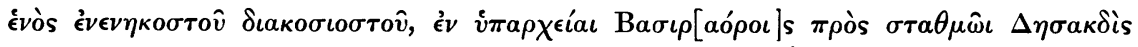

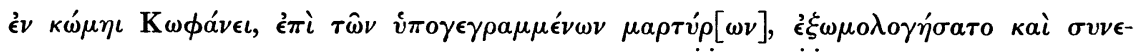

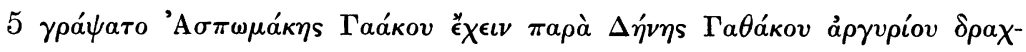

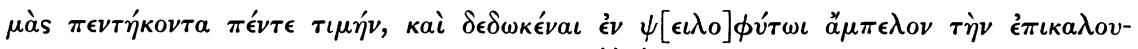

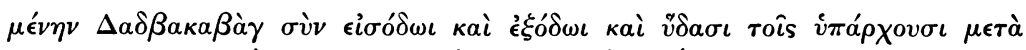

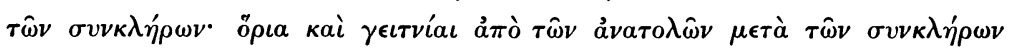

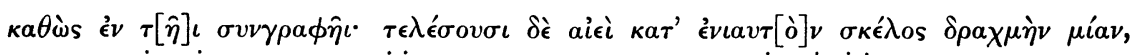

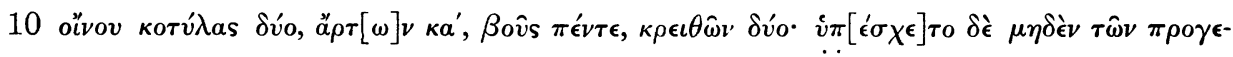

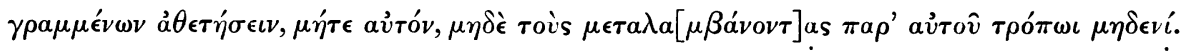

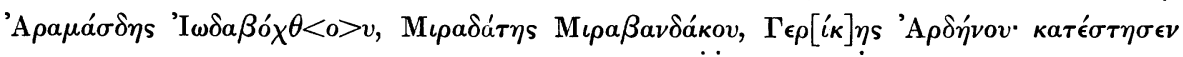

13 'A $\rho \theta \alpha \sigma \theta \alpha \dot{\tau} \eta \mathbf{s} \Delta \alpha \rho \gamma \eta^{\prime} \nu o v$.
$\begin{array}{lll}0 & 0 & 0\end{array}$
0
O 0
0
$0 \quad 0 \quad 0$
$\mathrm{O}$
$\mathrm{O} \stackrel{\text { (string }}{\text { holes })}$

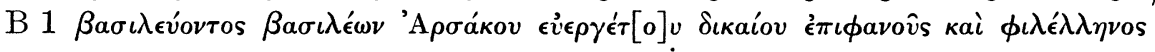

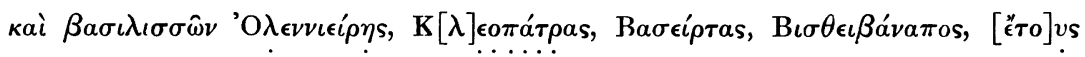

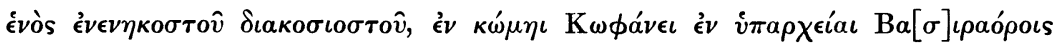

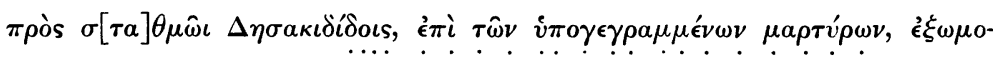

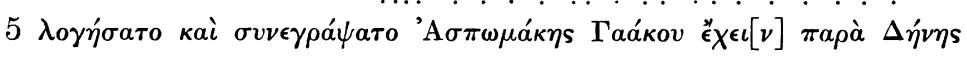

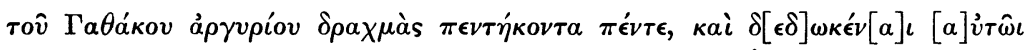

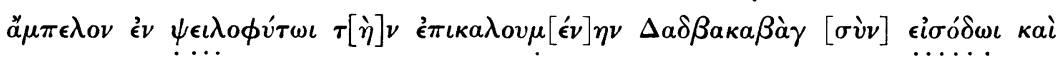

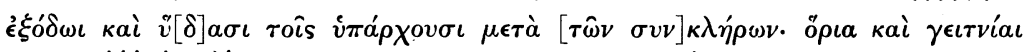

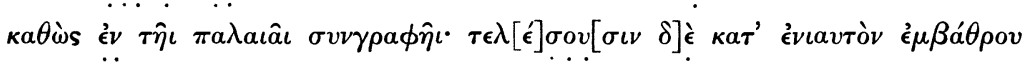

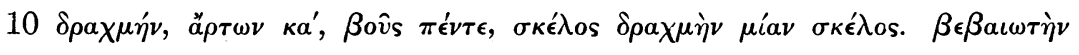

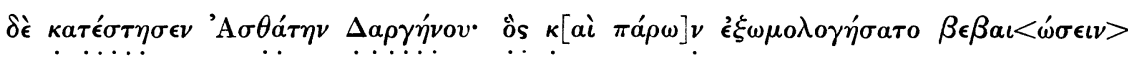

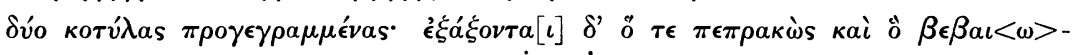

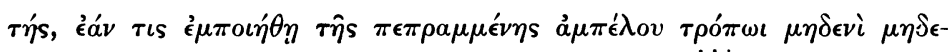

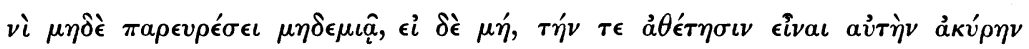

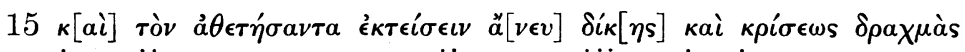

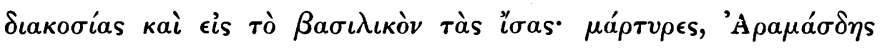

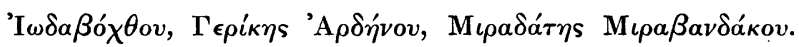
A 3, $\Delta \eta \sigma a \kappa \iota \delta i ́ s(?)$.

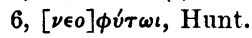
8, орıа каا $\gamma \epsilon \iota \tau \nu i ́ a \iota$, Bell.

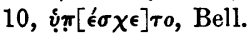

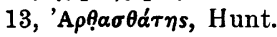

B 4, $\Delta \eta \sigma \alpha \kappa i \delta i a \tau o s$ or . . . бos, Hunt.

11, ğ $\kappa[a\} \pi a ́ \rho \omega]$, , Hunt.

14, à $\dot{v} \rho \eta \nu$, the $\eta$ is queer but certainly not $o$. 15, $\measuredangle[\nu \in v] \delta_{\mathfrak{s} k}^{\prime}[\eta s]$, Bell. 


\section{PARCHMENTS OF THE PARTHIAN PERIOD FROM AVROMAN 31}

\section{Translation $\mathbf{I}$.}

What is identical in $A$ and $B$ is in large type: otherwise the versions run parallel, $A$ above and $B$ below: - - - is put where one version has nothing to correspond to words in the other. The division of lines follows $B$, the fuller version, but the beginnings of $l l .5,10$, etc., in $A$ are marked ${ }^{a}$.

1 In the reign of the King of Kings, Arsaces, the Benefactor, the Just, the Manifest and the Philhellene, and of the Queens, Siace his compaternal sister and wife, and Aryazate surnamed Automa, daughter of the Great King Tigranes and his wife,

5 and of Azate his compaternal sister and wife, in the year 225, in the month Apellaeus, in the hyparchy Baiseira, near the station Baithabarta in the village Copanis, before the witnesses hereunder written, acknowledgment and agreement were made by Baraces and Sobēnes, the sons of Maiphorres, that they had received from Gathaces,

10 the son of Oipates, in coined ${ }^{a}$ money thirty (altered in $B$ to forty) drachmae the price of a vineyard situate in the village Copanis, known as $\left\{\begin{array}{c}\text { Dadbakanras } \\ \text { Ganzace }\end{array}\right\}$ his own share $\left\{\begin{array}{c}\text { the share } \\ -\ldots \ldots\end{array}\right\}$ due to him $\left\{\begin{array}{c}-- \\ \text { his }\end{array}\right\}$

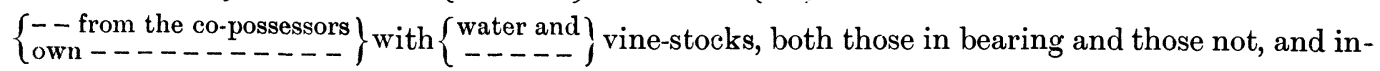
gress and egress and all that pertain to $\left\{\begin{array}{l}\text { it: let the one part belong } \\ \text { him, half }\end{array}\right.$

15 to Baraces and $a\left\{\begin{array}{c}\text { the one part } \\ \text { half }\end{array}\right\}$ to Gathaces, on condition that on taking possession the afore-

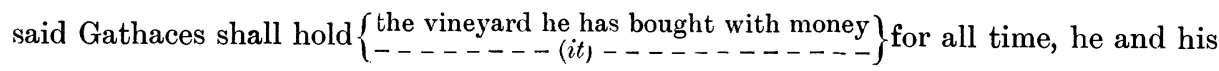
descendants, $\left\{\begin{array}{l}-\overline{\text { for all time }}\} \\ \}\end{array}\right.$ ly $\left\{\begin{array}{l}\text { in common } \\ -----\end{array}\right\}$ the things $\left\{\begin{array}{l}\text { written } \\ \text { found }\end{array}\right\}$ in the $\left\{\begin{array}{l}\text { old } \\ --\end{array}\right\}$ agreement all in full

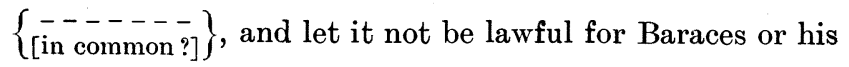

$20\left\{\begin{array}{c}\text { brother } \\ \text { descendants }\end{array}\right\}$ or his $\left\{\begin{array}{c}\text { descendants } \\ \text { brother }\end{array}\right\}$ or anyone $\left\{\begin{array}{l}\text { else }{ }^{a} \text { acting on } \\ \text { taking over the vi- }\end{array}\right.$ $\left\{\begin{array}{l}\text { their behalf } \\ \text { neyard from them }\end{array}\right\}$ to dispossess Gathaces $\left\{\begin{array}{l}\text { of the vineyard he has bought with money either him } \\ -\end{array}\right.$ or his descendants : and whoever may dispossess him, or, in case of anyone else attempting to dispossess [him, may fail to stand by and finally eject (the intruder) and acquit all claims, he shall lose his rights and pay double the price he received and an additional

25 fine of 200 drachmae and to the King an aequal sum : but $\left\{\begin{array}{l}-----j \\ \text { likewise }\end{array}\right\}$ if Gathaces too neglect the vineyard and fail to keep it in good order, $\left\{\begin{array}{l}\text { let him } \\ \text { he shall }\end{array}\right\}$ pay the same fine; also $\left\{\begin{array}{l}-\overline{\text { he shall have }}\} \\ -\overline{-}\end{array}\right.$ the water $\left\{\begin{array}{c}\text { for one }[d a y] \text { in eight (?) by day half, and of what is let in } \\ \text { the share that is due to him with the co-possessors. }\end{array}\right\}$ $\left\{\begin{array}{ll}\text { by night half. Witnesses }- & \text { As surety and co-responsible [Baraces and Sobènes ?] appointed }\end{array}\right\}$ 


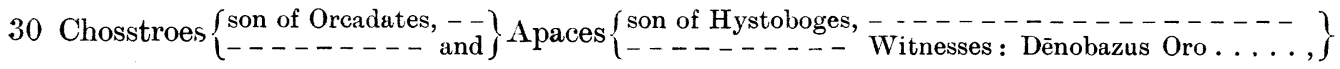

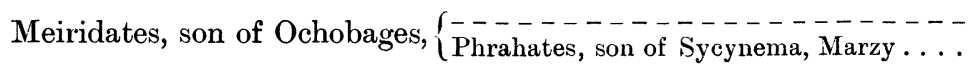

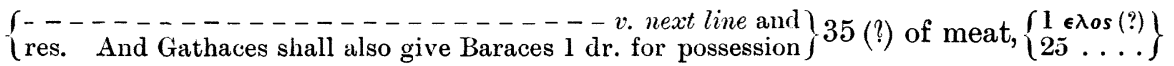

50 baskets (?) of loaves, $\left\{\begin{array}{c}\text { a8 oxen, } \\ v \text {. next line }\end{array}\right\} 2$ co(tylae ?) of wine $\{[$ and $] 1$ dr. for possession $\}$

$\{-($ between.the lines $25 \ldots ., 8$ oxen (?)). And Baraces too shall give Gathaces from the wine-press the $\}$

$34\left\{\begin{array}{l}----\bar{c}----\ldots \text { and pressed grapes }\end{array}\right\}$.

\section{Translation II.}

1 In the reign of the King of Kings, Arsaces, the Benefactor, the Just, the Manifest and the and of the Queens, Olennieire, Cleopatra, Baseirta, Bistheibanaps, in the year

[Philhellene, two hundred and ninety one $\left\{\begin{array}{l}\text { in the hyparchy Basiraora, near the station Dēsacdis } \\ \text { in the village Cöphanis, in the hyparchy Basiraora }\end{array}\right\}$ $\left\{\begin{array}{l}\text { in the village Cōphanis, } \\ \text { near the station Dēsacidida, }\end{array}\right\}$ before the witnesses hereunder written, acknow-

5 ledgment and agree ${ }^{a}$ ment were made by Aspōmaces, son of Gaaces, that he had received from son of Gathaces fifty-five drachmae in money $\left\{\begin{array}{c}\text { as a price } \\ ----\end{array}\right\}$ and had given $\left\{\begin{array}{c}-\overline{\mathrm{him}} \\ \}\end{array}\right.$

[Denes the vineyard in the open country known as Dadbakabag with ingress and egress and the waters belonging in common with the co-possessors : the boundaries and abutments

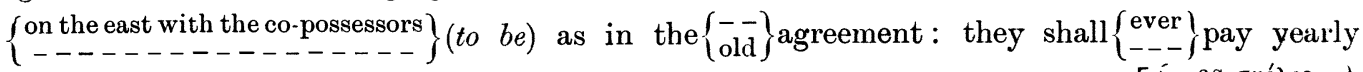

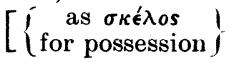

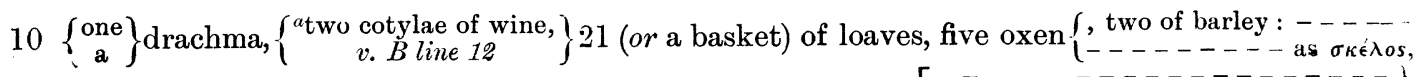

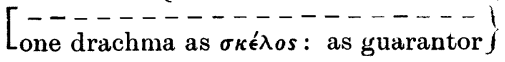

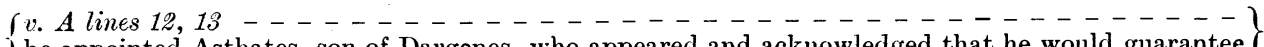
$\{$ he appointed Asthates, son of Dargenes, who appeared and acknowledged that he would guarantee $\}$

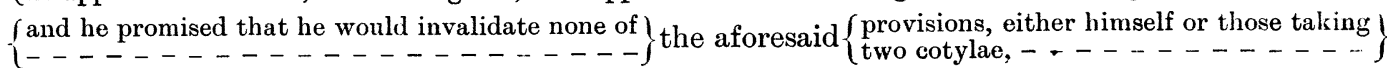
$\{$ over from him, $\{$ tor, if any one lay claim to the vineyard that has now been sold) $\}$ in no way whatever. $\left\{\begin{array}{l}\text { I what } \\ \text { to }\end{array}\right\}$

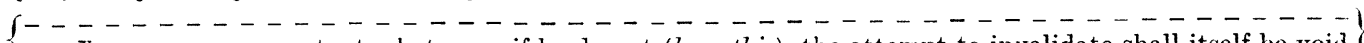
$\{$ everl] nor upon any pretext whatever : if he do not (keep this), the attempt to invalidate shall itself be void $\}$

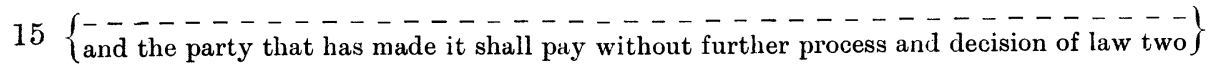
$\left\{\begin{array}{l}\text { hundred drachmae and the same sum to the King's treasury. Witnesses, }\end{array}\right\}$ Aramasdes son of Iodabochthes, $\left\{\begin{array}{l}\text { Miradates, son of Mirabandaces, Gerices, son of Ardēnes. He appointed } \\ \text { Gerices, son of Ardēnes, Miradates, son of Mirabandaces. } \ldots \ldots-\ldots\end{array}\right.$ $\{($ guarantor $)$ Arthasthates, son of Dargēnes $\}$ $\left\{\begin{array}{l}\text { ( } . \text { line } 11) \ldots \ldots \ldots \\ \text { l }\end{array}\right.$ 


\section{Historical Interest.}

The interest presented by the contents of our documents, as transcribed and translated, falls into three main divisions, historical, linguistic, and legal. The mere fact that at the time and place in which they were composed Greek should have been the language chosen is unexpected, also the elements of the dates add a little to our knowledge of the Parthian kingdom: the forms in which some of the proper names occur throw fresh light upon the time when important sound changes took place in Iranian speech, while students of Hellenistic Greek are not indifferent to specimens from a new region; finally students of ancient law will find in the texts and in the very carelessness with which they were put together something worth comparing with the innumerable documents of Grecian Egypt.

The dating formulae give the official name of the King Arsaces, his style, the names of his Queens and the year of some era. It is clear at first sight that we have to do with the king of Parthia; no king of a subordinate kingdom such as Persis, Elymais, Media Atropatene, or even Armenia (except under Tigranes) would dare to call himself King of Kings. As all the Parthian kings bore the same official name, and as none of these queens seem to be known, this gives us little by which to check the remaining chronological elements and thereby determine what era was used.

Both style and era have light thrown upon them by being compared with those used upon certain cuneiform tablets, ${ }^{15}$ two Greek inscriptions from Babylon, one from Delos, and the Parthian coinage. ${ }^{15 a}$ The tablets are some of them legal documents, others astronomical records, others (Reisner's) hymns to deities. Under the Seleucids a single date is given, the year of the Seleucid Era (A.Sel.); even under Seleucus I. it is not a regnal year but the year of an era, hence the translation of $a$ is not Anno viII Seleuci regis, but Seleuco rege. As soon as we get the name Arsaces, the dates become double (e.g. $c$ ); the year of a new era generally called the 'Arsacid' (A.Ars.) is put before the Seleucid year, though the Seleucid still occurs alone (e.g. $f, o)$ : I know of no certain example of the Arsacid year appearing without the Seleucid.

\footnotetext{
15 Some hundred and fifty are known with dates of the Seleucid Era and some forty with the addition of the Arsacid (see below). The first to publish one of these was G. Smith, Assyrian Discoveries, p. 389, but we owe most knowleilge of them to Fr. J. N. Strassmaier, Zeitschrift für Assyriologie, iii. (1888), pp. 129158, 'A rsaciden Inschriften'; iv. (1889), pp. 76-89 (J. Epping) ; v. (1890), pp. 341-366 (Epping and Strassmaier), 'Neue Babylonische Planeten 'Tafeln,' continued in vi. (1891), pp. 89-202, 217-244 ; vii. (1892), pp. 197-209, 'Einige chronologische Daten aus astronomischer Rechnungen'; historical results summed up in viii. (1893), pp. 106-113, 'Zur Chronologie der Seleuciden' ; cf. Fr. F. X. Kugler, Zt. f. Ass. H.S.-VOL. XXXV.
}

xv. pp. 178-209, 'Zur Erklärung der Babylonischen Mondtafeln'; of G. A. Reisner's 'Sumerisch-Babylonische Hymnen nach Thontafeln Griechischer Zeit' (Kgl. Museen zu Berlin, Mitth. aus der Orient. Samml. x. 1896) only a dozen have Arsacid dates, the colophons being generally broken : the editor gives no translation or transcription; this is supplied in a few cases by $\mathrm{M} \rightarrow \mathrm{M}$. A. Hussey, Amer. Journ. of Sem. Lang. xxiii. (1906-7), p. 142 : A. T. Clay, Babylonian Records in the Library of J. Pierpunt Morgan, ii. (N.Y. 1913), 'Legal Documents from Erech dated in the Seleucid Era,' includes three with Arsacid dates: others are still unpublished.

15a W. Wroth, B.M.C. Parthia, p. lxv. 


\section{Dating Formulae of certain Cuneiform Tablets and Greek INSCRIPTIONS.}

B. C.

(c $304 / 3$

b $265 / 4$
A. Ars.

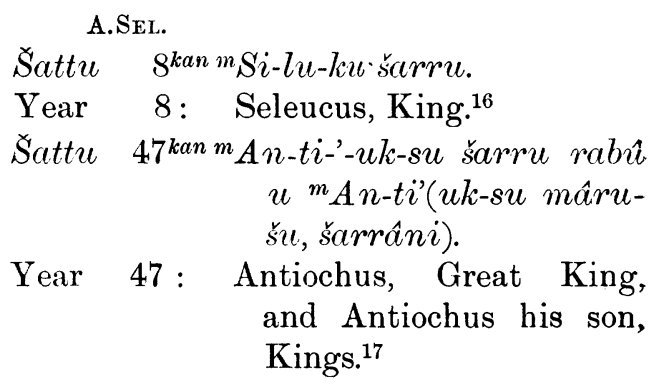

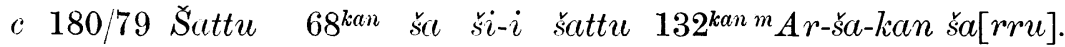
Year 68 which is year 132: Arsaces, King. ${ }^{18}$

d c. 139 (date lost)

${ }^{m} A r$-sak-' u 'rRi . . . nu ummi-šu, šarrâni.

Arsaces and $\mathrm{Ri} \ldots$... nu his mother, Kings. ${ }^{19}$

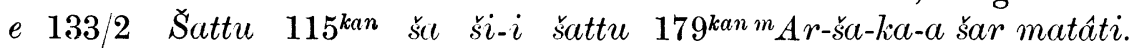

Year 115 which is year 179: Arsaces, King of countries.

$f \quad 110 / 09$

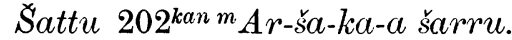

Year 202: Arsaces, King. ${ }^{20}$

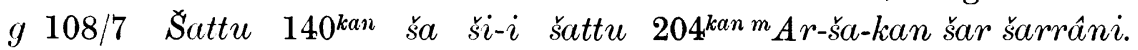
Year 140 which is year 204: Arsaces, King of Kings. ${ }^{21}$

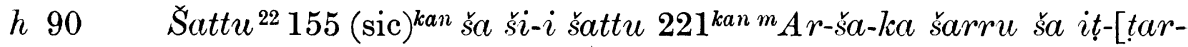
$r i$ - $] d i(?) \mid\left[{ }^{m} G u\right]-\operatorname{tar}(?)-$ $z a(?)-a \quad u \quad f A$ - 'si-'-a-ba$\operatorname{tum}(?)\left[{ }^{f} a s_{s} a t i-s ̌ u ~ b e ̂ l t u\right]$ $\mid\left[\begin{array}{lll}u & f & .\end{array}.\right]-s ̌ a-a t$ amel(?) tir ?) fašsati(?)-šu bêltu.

Year 155 (157?) which is year 221: Arsaces, King, who was continued as Gotarzes, and Aši'abatum [his wife, Lady and ...] šât amel tir (?) his wife, Lady. ${ }^{23}$
16 Erech. A. T. Clay, op. cit. No. 1, pp. 36, $37:^{m}$ and $f$ are the 'determinatives' for masculine and feminine persons, and kan for numerals.

17 Strassmaier, Zt. f. Ass. viii. p. 108: he always writes sanat the construct for šattu, and $47^{\text {tu }}$ the ordinal for $47^{\text {kan }}$.

18 Strassmaier, op. cit. p. 110.

19 Erech. Clay, op. cit. No. 53, pp. 13, 33, 87. It is written by the scribe of his No. 53 dated A.Sel. 173.

${ }^{20}$ e, $f$, Strassmaier, op. cit. p. 111.
${ }^{21}$ Strassmaier, op. cit. p. 111. 'Ten examples of this formula bring us down to Tišri $157=221$ (B.c. 91), the date of Berlin, V.A.Th. 245, Reisner, No. 46, pp. viii, 82.

${ }^{22}$ The month is Adar II., the last of the year.

${ }^{23}$ Berlin, V.A.Th. 265, 728, Reisner, No. 51, p. 93, 11. 9-11. Though the signs are not clear, the first wife's name gives us the right to supplements according to $i$ and $j$. For the translation, see below, p. 40 n. 53 . 
B.C. A.ARs.

A.SEL.

i 88/7 Sattu $160^{k a n}$ ša ši-i šattu $224^{k a n m} A r-s ̌ a-k a-a \quad \check{s} a \quad i-t a[r-r i-$ du] ${ }^{m} G u-t a r-z a-a$ šarru $u{ }^{f} A-s i-b a-a-t[u m]{ }^{f} a s^{\prime}-$ šati-šu bêltu.

Year 160 which is year 224: Arsaces, who was continued as Gotarzes, King, and Asibâtum, his wife, Lady. ${ }^{24}$

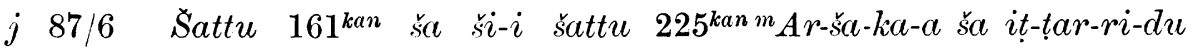
${ }^{m} G u$-tar-za-a šarru u ${ }^{f} A-s i-[b a t u m, \quad a \check{s ̌ s} a t i-s ̌ u$ bêltu].

Year 161 which is year 225: Arsaces, who was continued as Gotarzes, King, and Asi[bâtum, his wife, Lady]. ${ }^{25}$

$k \quad$ (date lost)

${ }^{m} A r-s ̌ a-l k a-\alpha$ šarru ša šumu$s^{\prime} u^{m} G u$-tar-za-a.

Arsaces, King, whose name is Gotarzes. ${ }^{26}$

$l \quad 86 / 5 \quad \breve{S} a t t u \quad 162^{k a n} \quad \check{s} a \quad \check{s} i-i \quad \check{s} a t t u \quad 226^{\text {kan } m} A r$-ša-kan šarru.

Year 162 which is year 226: Arsaces, King. ${ }^{27}$

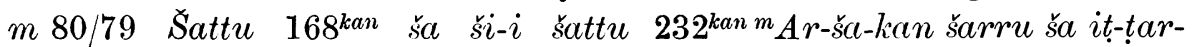
$r i-d u^{m} U-r u-d a-a$ šarru.

Year 168 which is year 232: Arsaces, King; whowas continued as Orodes, King. ${ }^{28}$

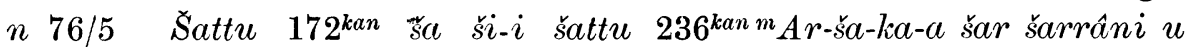
${ }^{f} I z-b u-b a r-z a-a$ ahati-šu šarratu.

Year 172 which is year 236: Arsaces, King of Kings, and Izbubarzâ, his sister, Queen.

o $\quad 70 / 69$

Sattu $242^{\text {kan } n} A r-<\zeta ̌ c-k a-a$ šarru.

Year 242: $\operatorname{Ar}\left[\right.$ sa]ces, King. ${ }^{28 a}$

24 Brit. Mus. Rm. 844. Brit. Mus. Rm. 710 shows part of this formula for the preceding year, $159=223 ; v$. Zt. f. Ass. vi. p. 226 , viii. p. 112.

${ }_{25}$ Pennsylvania Mus. 9. 21-7-88, corrected by reference to the original ; cf. $Z t$. $f$. Ass. vi. p. 222 ; Eb. Schrader, $S B . d . k . p r . A k . d . W$. zu Berlin, 1891, p. 3.

${ }^{26} Z$ Zt. f. Ass. vi. p. 226.

27 Berlin, V.A.Th. 573, Reisner, No. 27, pp. viii. (206 is misprint for 226), 54, rev. 1.15 ; ib. No. 55, pp. ix, 155 , rev. l. 33 , bears date $163=226$, probably a mistake for 227 ; Strassmaier, Zt. f. Ass. v. p. 355 , viii. p. 112 , gives year $164=228$; and Reisner, No. 49, pp. ix. 89 , l. 21 , year $[167]=231$ (B.c. $81-80$ ) : all these have the same formula.

28 Brit. Mus. Rm. IV. 118 A ; Zt.f. Ass. iii. p. 135 , iv. p. 78 (Epping), viii. p. 112, wrongly read šar šarrâni : see Schrader, SB. d. k. pr. Ak. d. W. zu Berlin, 1890, p. 1327.

28a $n$, o, Strassmaier, Zt. f. Ass. viii. p. 112. I) 2 
B.C.

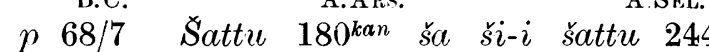

A. SEL. ir(?)-ri-ta-na-a ašsatišu, šarratu.

Year 180 which is year 244: Arsaces, King, and Pîritanâ, his wife, Queen. ${ }^{29}$

$q 35 / 4 \quad$ Sattu $213^{k a n} \quad \check{a} a \quad s ̌ i-i \quad s ̌ a t t u \quad 277^{k a n m} A r$-ša-kan šar šarrâni. Year 213 which is year 277: Arsaces, King of Kings. ${ }^{30}$

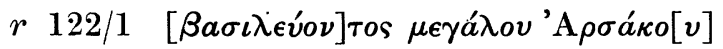

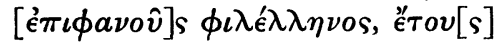

vac. $\dot{\omega} s$ ó $\beta a \sigma \iota \lambda \epsilon \dot{v} s\left[{ }^{\prime \prime}\right] \gamma[\epsilon \iota]$

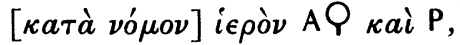

A.Sel. 191

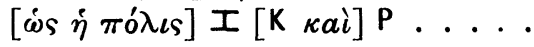

A.Ars. 127

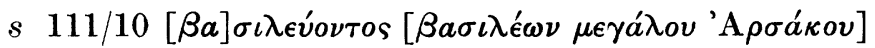

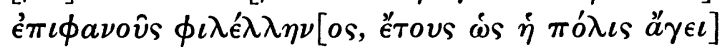

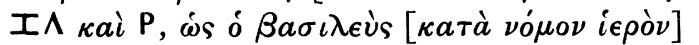
$\mathrm{B} \Sigma, \kappa . \tau . \lambda$.

A.Ars. 137

A.Sel. $202^{31}$

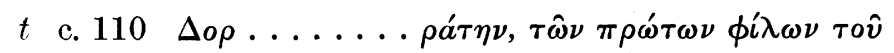

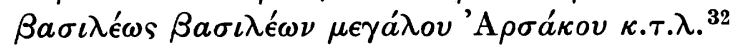

It is not indeed self-evident that the second era of these double dates is the Seleucid, as the Arsacids are not known to have got possession of Babylonia till between 144 and 139 B.c.; ${ }^{33}$ but $c$ seems to have nothing wrong with it and we must suppose that the Parthians made a successful raid during the weak reign of Seleucus IV. Philopator: so the temporary victory of Antiochus VII. Sidetes in 130 B.c. is recorded by a Seleucid date. ${ }^{34}$ Also various Arsaces dates published by Strassmaier have caused difficulties, though nearly all of them may be accounted for..$^{35}$ However, these difficulties and the fact that we know of no Gotarzes about 88 B.c. or Orodes about 80 , led Professor Schrader ${ }^{36}$ to suggest that we had two

29 Strassmaier, Zt.f. Ass, viii. p. 112.

30 Strassmaier, Zt. $f$. Ass. vii. p. 204. This is the latest cuneiform date known, Oppert's year 5 of Pi-ha-ri-su, king of Pa-ar-su, Doc. Juridiques de l'Assyrie, p. 341, not being accepted as Pacorus.

31 Both from Babylon, restored by B. Haussoullier, 'Inscriptions Grecques de Babylone,' Klio, ix. (1909), p. 353, Nos. 2 and 1 ; but $I$ am responsible for $\beta a \sigma \iota \lambda \in \dot{v} o \nu \tau o s \quad \beta \alpha \sigma \iota$ $\lambda \epsilon \omega \nu$ in s. Mr. Haussoullier says 'quand ils [sc. les Grecs] emploient le verbe $\beta a \sigma \iota \lambda \epsilon \dot{v} o v \tau o s$, ... le génitif $\beta a \sigma \iota \lambda \epsilon ́ \omega \nu$ n'est plus de mise et ils le suppriment,' but it fills out the line well, and I give reasons for it below. The text is a

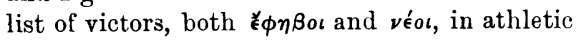
contests.

32 Delos: Dittenberger, O.G.I. i. 430.

33 Bevan, House of Seleucus, ii. p. 233 ; E. Breccia, Klio, v. 'Mitridate il Grande di Partia,' pp. 49-54.

34 A.Sel. 182 : Zt. f. Ass. p. 202 ; Reisner, Hymnen, No. 25, v. A. T. Clay, op. cit. p. 12.

35 There must be something wrong about šattu $108^{k a n} A r-s ̌ a-k a-a$ šar šarrâni in Zt. $f$. Ass. iii. (1888), p. 130, No. 1, unless E. Breccia, Klio, v. p. 41 , n. 1 , is right in taking it as a solitary Arsacid date without a.Seleucid, and so giving the title šar šarrâni to Mithradates I.; more probably it ought to be A.Sel. 208, as Strassmaier says (Zt. f. Ass. viii. p. 111) that $g$ (above) is the first with that title. The 156 of $Z t$. f. Ass. iii. p. 130, No. 2, is the A.Ars. of a double date which has lost its A.Sel. ; the rest are mostly corrected in $Z t$. $f$. Ass. viii. p. 112 .

36 SB. Berl. 1890, pp. 1319-1332, 'Die Datirung der babylonischen sog. Arsacideninschriften,' ' Nachtrag,' ib. 1891, p. 3. 
Arsacid Eras starting, one from the accession of Phrahates I. in 181 B.C., the other from that of Mithradates II. about 117 B.c. This would bring Gotarzes into the known place, but does not help for Orodes or square with the astronomical phenomena as worked out by Strassmaier and Epping, and on the whole endorsed by Kugler.

The latter fixes the beginning of the Seleucid Era as found on the tablets at 1 Nisan (April, the first month of the Semitic year) 311 B.c., and that of the Arsacid Era at 1 Nisan 247 B.c., just 64 years later. The ordinary reckoning for the Seleucid Era starts from the beginning of the Macedonian year 1 Dius (October?) 312 B.c. : but we know from Ptolemy ${ }^{37}$ that there was a modification of it $\kappa a \tau \dot{\alpha} \mathrm{X} a \lambda \delta a i_{o v s}{ }^{38}$ C. F. Lehmann (-Haupt) ${ }^{39}$ has suggested that, just as the ordinary Seleucid Era beginning in October was shifted by the Babylonians to begin in the following Nisan (April), so the Babylonian Arsacid Era that also began in Nisan was an accommodation of a true Arsacid Era which could go back to the true date of Tiridates' accession, $247 / 6$, B.C. ; Eusebius in his tables gives for this event Ol. 133, and this is its first year. But if Mr. Haussoullier is right in restoring these Greek double dates from Babylon, very likely the 'Arsacid' date was a purely Babylonian matter. Note that in $s$ the dates 137 and 202 differ by 65 . Mr. Haussoullier thinks the reason to be that having less regard for the Arsacid than for the Seleucid Era the Greeks shifted it to begin with October, but it seeins natural that they had rather kept to the original calculation of the Seleucid Era from October 312. Among the many cuneiform tablets with double dates only very few have a difference other than 64 : these are probably due to mistakes. ${ }^{40}$ The dates on Parthian coins, rare before Phrahates IV., A.Sel. 276=38 B.C., are always supposed to be in the ordinary Seleucid reckoning. ${ }^{41}$

It seems therefore certain that both Eras as found in cuneiform sources go back to 1 Nisan B.c. 311 and 247 respectively, but likely that the Seleucid Era as used in Greek inscriptions, in documents like ours, and probably on coins, goes back to 1 Dius 312 B.C. Accordingly the date of I.,

37 Almagest, ix. 7 ; xi. 7 : ell. Heiberg, I. ii. pp. $267,419$.

38 . W. Wroth, op. cit. p. lxv, and his convenient table of the ordinary or Greek Seleucid Era, p. 282. F. K. Ginzel, Handbuch der mathematischen und technischen Chronologie, establishes the beginning of the ordinary Seleu. cid Era (iii. 1914, p. 41) and of the 'Babylonian' and 'Arsacid' Eras (i. 1906, pp. 136, 137) as above. Fr. F. X. Kugler, Stcrnkunde und Sterndienst in Babcl, i. (1907), p. 214, coneurs.

39 'Zur Arsaciden Fra,' Klio, v. (1905), pp. 128-130.

40 Strassmaier, Zt. f. Ass. iii. p. 131, No. 1, ll. 7,8, A.Ars. $152=$ A.Sel. 217 ; and viii. p. 111 , A.Ars. $111=$ A.Sel. $174 ; h$ above, Reisner, Hymnen, No. 51, introd. p. ix. A.Ars. $157 ?=$ A.Sel. 221, but text, p. 93, rev. 1. 9, A.Ars. 155 ; No. 55, introd. p. ix. A.Ars. 163 $=$ A.Sel. 227, but text, p. 155, rev. l. 33, A.Sel. 226. Kugler, ap. Haussoullier, says he knows of but one instance.

${ }^{41}$ Professor Rapson has suggested ( $\boldsymbol{N}^{\prime} \mathrm{um}$. Chron. 1893, p. 212) that a drachma bearing EKP is dated by the Arsacid Era, but $v$. Wroth, op. cit. p. 21, No. 10, and note 3 . EKP is in the exergue, the right place for a date; but there are unexplained monograms on other similar coins, and it may be that had the letters lent themselves thereto they would have appeared in the field as a monogram. 
Apellaeus A.Sel. 225, comes out at November 88 B.C. and II., A.Sel. 291, at $22 / 21$ B.C.

With regard to the royal style the comparison of our documents, the tablets, and the coins is very instructive. The King's titles in both I. and II. are alike and (save for $\kappa a i$ ) identical with the coin-legend first adopted by Orodes (57-37 B.c.) and continued by nearly all his successors, $\beta a \sigma \iota \lambda \epsilon \epsilon$ s

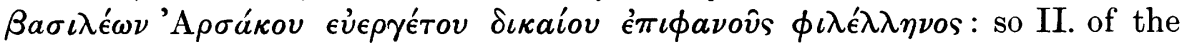
time of Phrahates IV. agrees exactly with his coins. ${ }^{42}$ But by 88 B.c. the complete formula had not occurred upon coins; however, the way had been prepared for it by various approximations : $\phi \iota \lambda \epsilon \operatorname{e} \lambda \lambda \eta \nu o s$ appears on dated coins of Mithradates I. and of Himerus (?), and on one of Artabanus, who came between them : all kings after Mithradates II. seem to have used it: Himerus

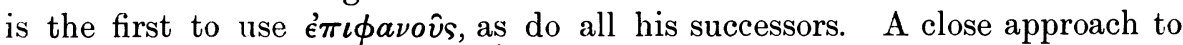
our formula is on certain drachmae assigned by Wroth (p. 35) to

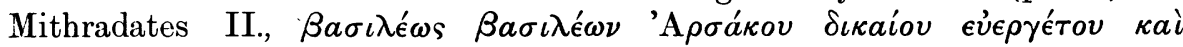

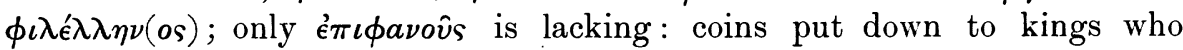
immediately succeeded to him have different combinations of the same

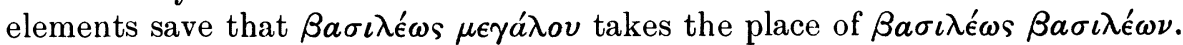
The variations in the epithets which follow the name do not probably represent anything very much, but the assumption of the title 'King of Kings' instead of 'Great King' 43 implies a definite claim to the suzerainty of Western Asia. On their coins the Arsacids had styled themselves ' King' or 'Great King' until Mithradates II., some of whose coins have 'King of Kings.' ${ }^{43 a}$ The coins assigned to his successors have 'Great King' until Mithradates III. in whose time 'King of Kings' is finally adopted. On the whole the tablets and Greek inscriptions support the numismatists; šarru, šar matâti or šarru rabû, ' King,' ' King of Lands,' or 'Great King,' are used on the former (e.g. $c, d, e, f$ ) down to 110 B.c. : from 108 B.C., the middle of the reign of Mithradates II., to Tišri ${ }^{44} 91$ we have šar šarrâni, 'King of Kings' (e.g. g): so $r$ from 122 B.c. has $\beta a \sigma \iota \lambda \epsilon ́ \omega s ~ \mu \epsilon \gamma a ́ \lambda o v$ and almost the same formula as the coin ascribed to Himerus dated 123 B.C., ${ }^{45} \mathrm{~s}$ is doubtful, and $t$ of about 110 B.c. has $\beta a \sigma \iota \lambda \epsilon^{\omega} \omega s \beta a \sigma \imath \lambda \epsilon \omega \nu$ : šarru occurs from 90 to 80 B.c. $(h, i, j, k, l, m)$ and again c. 68 B.c. $(p)$ in the reign of Phrahates III., to whom Pompey definitely refused the title 'King of Kings,' ${ }^{46}$ and of course $q$ in 35 B.c. has šar šarrâni. But as against Wroth's assignment of the coins we have šar šarrâni in 76 B.c. $(n)$, and in view of their precise dating the tablets give the better lead. I am inclined to wonder whether among the coins that Wroth assigns to Mithradates II., all his Class II., those with a helmet

42 I have mostly followed Mr. Wroth, B.M.C. Parthia, and my new material has supported his conclusions in one or two points; but the attribution of undated coins to particular kings is so subjective that it is very unsafe to rely on numismatic evidence.

43 For the significance of the titles, v. E. R. Bevan, 'Antiochus III. and his title Great King,' J.H.S. xxii. p. 241. 43a So Wroth, op. cit. p. xxiii sqq.; Num. Chron. 1900, p. 186 sqq. : Gardner had said Mithr. I.

44 The sign for this month is not quite certain, but $h$ must be subsequent, being dated Adar II., the last month of the year.

45 Wroth, op. cit. p. $194 ;$ B.M.C. pp. xxiii, 23.

46 Plutarch, Pompey, 38. 
and $\beta a \sigma \iota \lambda \epsilon^{\prime} \omega s \beta a \sigma \iota \lambda \epsilon ́ \omega \nu$, should not rather be given to a king reigning c. 75 B.C., or at any rate the drachmae above mentioned, on which the full inscription seems to mark a later date.

The absence of $\beta a \sigma \iota \lambda \epsilon^{\prime} \omega s \beta a \sigma \imath \lambda \epsilon^{\prime} \omega \nu$ on the coins had been explained by the fact that it coincided closely with the time when Tigranes of Armenia was claiming the highest place in Western Asia; the tablets seem to suggest that if some Parthian kings recognised his pretensions, others resisted them. It is not unlikely that the former received his support in an internal struggle against rivals who did not rely on or bow down before the Armenian King of Kings.

Our documents agree with the cuneiform tablets in naming queens side by side with the kings. ${ }^{47}$ This was the practice of the Ptolemies, but not apparently of other Oriental states. ${ }^{48}$ Further, I. and tablet $n$ tell us that the queen was, again as among the Ptolemies and perhaps among the Seleucids, ${ }^{49}$ the king's sister. ${ }^{49 a}$ We knew from Herodian (iv. 10) that the kings took their wives among the descendants of Arsaces, and it might have been expected that they should marry their sisters as this practice, if not enjoined in the Avesta, is certainly approved in Pahlavi literature..$^{50} \mathrm{We}$ may notice that foreign queens were also taken; for instance, Aryazate or Automa the daughter of Tigranes in I. and the Cleopatra in II. Strabo (XI. xiii. 1) speaks of a Parthian queen from Atropatene and Plutarch ${ }^{51}$ of Greek concubines; compare the case of Musa below.

In the case of tablet $d$ it looks as if we had to do with a queen-regent and a minor, that is, with Phrahates II., who is usually supposed to have come to the throne about 138 B.C.: it is a pity that the exact date of the tablet is lost. The tablets quoted under $i$ and $j$, A.Sel.Bab. 223, 224, 225, overlap document I. A.Sel.Gr. 225 before and after. The reading ittaridu (itarridu or $i t(t)$ arridu) in $i, j$ and $m$, is due to Dr. L. W. King ${ }^{52}$ who very kindly

47 I have restored tablet $h$ as having uamed two queens, but it is possible that Dr. Johns should have vetoed this, as the characters given by Reisner are not exactly ${ }^{f}$ ašsati-š $u$. Aši ‘abatum may have been the principal queen and the other the queen kept at Babylon. The names seem Iranian: Aši 'abatum suggests ašivant, ‘ giving rewards,' and pati, 'lord,' or pāta, ‘ protected '; Pîritâna, pir, 'old man,' and tana, 'descendant'; Izbubarzâ, ispahi, 'soldier,' barzz, 'high,' or varoz, 'work': but these are mere guesses, and the derivations need not be sought in Iranian at all.

48 F. C. Burkitt, in notes to a revised translation of 'The Hymn of the Soul,' The Quest, v. No. 4 (1914), quotes our documents to illustrate the first lines of a letter to the exiled Prince, 'From thy Father, the King of Kings, from the Queen, thy Mother,-And from thy Brother, - to thee, Our Son in Egypt, be greeting'; but it is a family letter, not a state document. Kamnaskires of Elam does name his queen Anzaze on his coins: B. V. Head, Hist. Num. ${ }^{2}$ p. 822 ; A. de la Füye, Rev. Num. 1902, Pl. V. 2-6 ; A.Sel. 231.

49 Bevan, House of Seleucus, ii. p. 279.

49a So Lucan, viii. 404, iacuere sorores in regum thalamis, proves to be true.

${ }^{50}$ J. H. Moulton, Hibbert Lectures, 1913, 'Early Zoroastrianism,' pp. 205 sqq. Gutschmid, p. 43, suggests that Phriapatius called himself Philadelphus because of having complied with this custom, but the coins on which he founds this guess are assigned by Wroth to Artabanus I. (II.), who might so have expressed his regard for his great predecessor, Mithra. dates I. 1t is strange that the king of tablet $n$, who is said to have married his sister, is apparently Sinatruces, who came to the throne at the age of eighty.

${ }^{51}$ Crassus, 32 fin.

52 Letters dated 16 Oct., 9 and 11 Nov., 1914, 25 Jan. 1915. 
furnished me with the exact readings of the British Museum tablets and ascertained by writing out to Philadelphia that the tablet there agreed. Strassmaier had at first read the word (in $m$ ) as ittaris, afterwards Bezold and Schrader took it to be ustarridu and found it hard to explain. But. Dr. King is quite clear about the reading as given above and the translation is his ${ }^{53}$; it is well borne out by tablet $k .{ }^{54}$ Ašicabatum or Asibâtum in $h, i$, cannot be the same as any of the queens' names in document I., ${ }^{55}$ so the Arsaces-Gotarzes is probably not the Arsaces of I.; this was perhaps Mithradates II., who is known to have reigned till 88 B.c. ${ }^{56}$ Gotarzes may have been his son entrusted by him with the sub-kingdom of Babylon between 'Tišri and Adar II. A.Sel. 221, or else a rival admitting the hegemony of Armenia and so not claiming to be 'King of Kings.'

The next thirty years Justin merely sums up in Prologue XLII. with varia complurium regum successio: in his Epitome he jumps, apparently by mistake, from Mithradates II. to Mithradates III. and Orodes I. in 57 B.c. ${ }^{57}$ Other literary sources give us Sinatruces circa 77-70 B.c. and Phrahates III. c. 70-57. The tablets now enable us to put into the gap between 88 and 77 the name of Gotarzes who overlapped with and succeeded to Mithradates II., and Orodes c. 80 B.C., who can hardly have been the Orodes known to us in 57 B.c. Though there were no doubt other claimants, these new names make us less inclined to accept Artabanus as king from 88 to 77, as for his existence he depends entirely upon a conjecture of Gutschmid. ${ }^{58}$

53 'I suggest that we should read the verb as $i t(t) \operatorname{aridu,}$ the Nifal of tarâdu (טר). The ordinary meaning of taradu in Assyrian is " to pursue," but in this phrase I would assign to it the meaning "to follow, to continue" (in the Nifal, of course, "to be continued"). We may compare the Arabic tarada, which in St. X. has the meaning "to pass from one subject to another," "to pass from one class to another" (Dozy, Supplement aux Dictionnaires Arabes, ii. p. 33); while in St. II. it has the meaning "to prolong" (of the voice), and in St. VIII. "to flow in a regular course" (of water), " to be consecutive," "to continue uninterruptedly" (Lane, Arabic-English Lexicon, pp. 1838 f.). In Hebrew, too, tarad is used in the Qal with the meaning "to be continuous." The word only occurs in the phrase $\operatorname{delep}(h) t \bar{o} r \bar{e} d(h)$, "a continuous dripping," i.e. in which one drop pursues another (cf. Gesenius, Hebrew Lexicon, Oxford, 1906, p. 382). We have thus ample justification, both from Arabic and Hebrew, for assigning this new meaning to the root in Assyrian-or, rather, in late Babylonian. The root meaning of "pursuit" is well brought out in its Hebrew use; and this closely parallels its employment in the Arsacid date-formulaethe idea of continuity regarded as an uninterrupted succession of separate units.' Canon
C. H. W. Johns, Litt.D., Master of St. Catharine's College, who gave me the reference to Clay's book and interpreted Reisner's for me, found the old reading ustarridu unsatisfactory, and heartily welcomed Dr. King's solution of the difficulty.

54 A parallel to ša šumu-š $u$ Gutarzâ on tablet $k$ is perhaps found in the coin legends $\beta \alpha \sigma . \beta \alpha \sigma$.

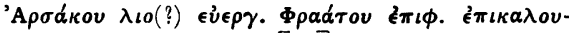

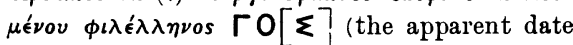
A.Sel. $273=40-39$ B.C., puts it into the reign of Phrahates IV. rather than Mithradates III. as Wroth, p. 66, suggests) and $\beta \alpha \sigma . \beta \alpha \sigma$.

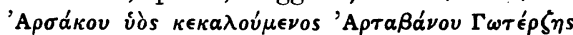
(Wroth, p. 165), where the nominative is an awkward attempt to clear the sense.

55 The second name of Aryazate, Automa, does a little suggest the end of Ašiabatum.

56 Gutschmid, p. 80.

57 Lib. XLII. ii. 3-6, iv. 1, 2.

58 Justin, Prolog. X LI. MSS. have: In Parthis ut est constihutum imperium per Arsacem regem. Successores deinde eius Artabanus et Tigrane cognomine deus: a quo subacta est Media et Mesopotamia. Dictusque in cxcessu Arabiae situs. In Bactrianis autem, etc. Prol. XLII. . . . utque Phraati successit rex Mithridates cognomine magnus qui Armcnis bcllum intulit. Inde repetitae origines Armeniorum et situs. Ut varia 
It would be rash to assign any particular groups of coins to these new kings, but probably some of those given by Wroth to his Artabanus II., having $\beta a \sigma \iota \lambda \epsilon^{\prime} \omega s \mu \epsilon \gamma a ́ \lambda o v$, belong to our Gotarzes and Orodes who called themselves šarru simply, while perhaps of those he assigns to Mithradates II., Class II. (with helmet and $\beta a \sigma . \beta a \sigma \iota \lambda \epsilon^{\prime} \omega \nu$ ) or at any rate part of the class, with the long inscription, should go to Sinatruces, within whose reign $n$ comes. But where dates and monograms fail us, the grounds for assigning coins to particular kings are so slight that the attempt is well nigh hopeless: we cánnot indeed be at all sure that a king might not let šar šarrâni continue in use on obscure native documents when he thought it politic to abandon the title on his coins with their wider range and intelligibility : still the case of Phrahates III. as exemplified on $o$ and $p$ argues for fair consistency in the matter.

Document I. therefore apparently belongs to the very end of the reign of Mithradates II. That he married a daughter of Tigranes is new. Tigranes had been a hostage in Parthia and probably her hand was bestowed in connexion with the action of Mithradates of Parthia in putting Tigranes, ${ }^{59}$ then about forty-five and well old enough to have a marriageable daughter, on the throne instead of Artoasdes I., Tigranes ceding him seventy valleys as a reward: this was in 94 B.c. Tigranes was still in alliance with Parthia in 86 B.C., and used this support to make himself master of Syria, but shortly after attacks by external enemies, probably at first on the N.E. border, and internal dissensions brought low the Parthians' power. Then it was that Tigranes took the title of 'King of Kings' and forced some Parthian kings or

complurium regum in Parthis successione imperium accepit Orodes, etc.

In Epitome XLI. Justin speaks of Arsaces (I.), his son Arsaces (II.), to whom he gives no other name, Phriapatius, Phrahates (I.), Mithradates (I.), makes a digression to things Bactrian and returus to Mithradates (I.), his conquest of Media and Elymais as far as the Euphrates. In Epitome XLII. we have Phrahates (II.), Artabanus, Mithradates (II.), his attack on Armenia, an account of Armenia, and then the deposition of Mithradates(III.). Gutschmid, Comm. Crit. in Prol. Tr. Pomp. ap. Justinum ed. Rühl, p. lxi., and Gesch. Irans, p. $81 \mathrm{n}$., said that the words successores to Arabiae situs now in Prol. XLI. have fallen out between Armeniorum et situs and ut varia in Prol. XLII. because of the homoeoteleuton situs, situs, and have been put back into the wrong place: so Artabanus would be a successor of Mithradates II. and so would Tigranes, as he conquered Mesopotamia from M.'s heirs and assumed the title King of Kings. This seems very harsh; also the lost account of Arabia could not conceivably have come at the end of XLII. which brings events down to 20 B.c. I prefer Vaillant's old correction Mithridates for Tigranes, so Artabanus becomes the second name of Arsaces II. (210-191), the only Arsacid without a second name. After a digression to Bactria we have mention of Mithradates I. and his conquests, which included Arabistán and gave good reason for an account of Arabia at the end of Book XLI. That Mithradates I. was called $\theta \epsilon o$ s we can infer from the coins assigned to his son and successor bearing the title

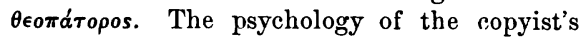
mistake is that he was sure that Eupator, the only Mithradates he knew of, did not conquer Mesopotamia, so he substituted the name that lay nearest in his mind. I note that Th. Reinach, Mithridate Eupator, p. 310, Justi, Ir. Namenbuch, pp. 31, 412, and Allotte de la Füye, Rev. Num. 1904, p. 321, doubt Gutschmid's view, though Wroth accepts it, pp. xix., xxxi.

59 Appian, Syr. 48, calls Tigranes the Great the son of Tigranes, and von Petrowicz thinks him an Arsacid; but Tigranes the Father was scarcely our Great King. 
pretenders to acquiesce in it. ${ }^{60}$ Perhaps it was the death of Mithradates II., his elderly son-in-law, that broke the bonds between Tigranes and Parthia and set him free to recover his seventy valleys and to invade not only Atropatene but Media proper somewhere about 86 B.c. Another daughter of Tigranes afterwards married Pacorus, three generations younger than Mithradates II. The Armenian princess has two names, one Aryazate, Iranian, and the other Automa, unintelligible, perhaps Armenian.

There can be no doubt that the Arsaces in Document II. is Phrahates IV., who used exactly the same titulature on his coins : but his dated tetradrachms stop at A.Sel. 289, two years before our document; 60 a probably this meant trouble of some sort or another. It was perhaps in this connexion that in 20 B.c. peace with Rome became so important that he actually restored the standards taken from Crassus and Antony, the proudest trophies of Parthian arms. In 10 or 9 B.C. he sent his sons to live under the protection of the Emperor. In 3-2 B.c. another son, Phrahataces, murdered him in conspiracy with his mother Musa, an Italian slave-girl sent as a present by Augustus. ${ }^{61}$ At first she had not been a real wife but moved by her beauty Phrahates had raised her to that position after the birth of her son. Oriental princes grow up quickly, but Phrahataces must have been born not long after the date of our document, which shews that in 21 B.c. Musa had not attained the dignity of queen. The names actually given do not lend themselves to interpretation, except Cleopatra, no doubt a daughter of one of the semi-Greek houses then still surviving in Western Asia.

\section{Places Mentioned.}

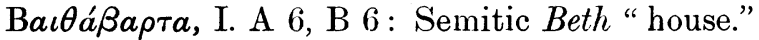

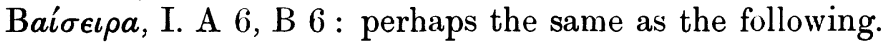

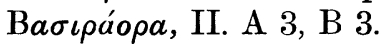

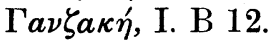

$\Delta a \delta \beta a \kappa a \beta a ́ \gamma$, II. A 7, B 7 : perhaps the same as the following.

$\Delta a \delta \beta a \kappa a \nu \rho a ́ s$, I. A 11.

$\Delta \eta \sigma a \kappa \delta i s$, II. A $3 ; \Delta \eta \sigma a \kappa \iota \delta i ́ \delta o \iota s, ~ I I . ~ 4$ (Dative).

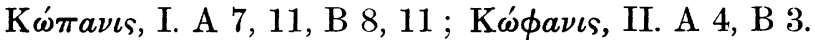

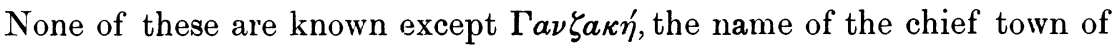
Atropatene, said to be Takht-i-Sulaiman, on a river running into Lake Urumia: here it seems to be a mistake as the corresponding text I. A 11

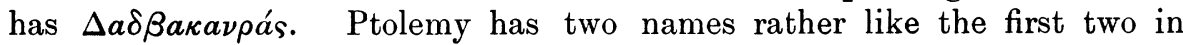
$\mathbf{B}^{\prime} \theta a \beta a$ or Bí $\rho \theta \beta a$ and B'́ $\sigma \sigma a \rho a$, but he sets them far from Avroman, somewhere near the Tigris and west of Nineveh, in his longitudes and latitudes $77^{\circ} 50^{\prime}-38^{\circ} 40^{\prime}$ and $77^{\circ}-37^{\circ} 20^{\prime}$. There is nothing surprising in a Semitic name like Baithabarta occurring so near the Semitic language

\footnotetext{
60 Justin, XL. i. 3 ; Gutschmid, p. 82.

60a Wroth, p. 107.

61 Josephus, Ant. Jud. XVIII. ii. 4 (40),
}

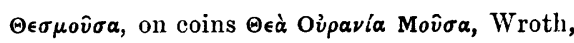
pp. 139-141, Pl. XXIV. 1-3. 
frontier. Dr. Saíd Khán gave me the names of several villages round Avroman, but none seemed to have any possible connexion with the names in the documents. There can be little doubt that $\mathbf{K} \omega \dot{\omega} \boldsymbol{\alpha} \iota \iota s$ and $\mathrm{K} \dot{\omega} \phi a \nu \iota s$ are

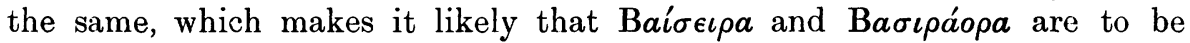
identified. We must allow for great carelessness in writing down the names; apart from the substitution of Ganzace in I. we have in II. the very different forms $\Delta \eta \sigma a \kappa \delta i s, \Delta \eta \sigma a \kappa i \delta i \delta o \iota s$ for what must be one name. That inclines me to think $\Delta a \delta \beta a \kappa a \beta a ́ y$ of II. and $\Delta a \delta \beta a \kappa a \nu \rho a ́ s$ of I. are one and the same name; it has an Iranian look; the termination baga means lot in one case and perhaps ras is something similar, and the first part may have the same elements as Bagdad (Deus dedit) in reverse order. It is true that $\Delta a \delta$ $\beta a \kappa a \beta a ́ r y$ is described as near the $\sigma \tau a \theta \mu o$ s Desakidida (or whatever the right

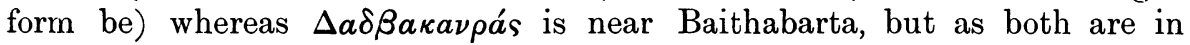
Cophanis, this might be due to a rearrangement of the $\sigma \tau a \theta \mu o i$ or poststations with dâk-bungalows on the king's highway. Isidorus Characenus writing $\pi \epsilon \rho i{ }^{2} \sigma \tau a \theta \mu \hat{\omega} \nu \Pi a \rho \theta \iota \kappa \hat{\omega} \nu$ seems to give lists of such along roads which Roman invaders might conceivably wish to use, but he mentions neither of these. As to the $\dot{v} \pi a \rho \chi i a \iota$-we hear of $\tilde{v} \pi a \rho \chi o \iota$ in Persia, ${ }^{61 a}$ and in the empire of the Seleucids ${ }^{62}$ and actually of $i \pi a \rho \chi \chi^{i} a \iota,{ }^{63}$ four or five making up one satrapy. The word may have survived under Roman rule ${ }^{64}$; still more likely is it to have remained under the Parthians, who seem to have made as few changes of organization as possible.

\section{Names of Persons. ${ }^{65}$}

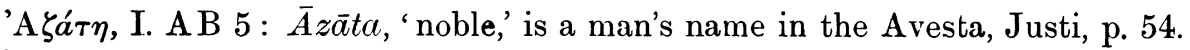
'A $a^{\prime} \kappa \eta s$, I. A 28, B 30 : cf. Apakan Wsemakan, general of Sapor II., Justi, p. 18.

'A $\rho \mu \mu a ́ \sigma \delta \eta s$, II. A 12, B 16 : Moulton suggests, Arəm-mazdah, 'with right wisdom'; cp. Aramaiti as popularly understood, 'right thinking,' cf. A. Carnoy, Muséon, n.s. xiii. p. $127 s q q$.

'A $\rho \theta a \sigma \theta a ́ \tau \eta s$, II. A 12, 'A $\sigma \theta a \dot{\tau} \eta s$, B $11^{65 a}$ : perhaps arta, 'pure': Carnoy compares astāta, 'not standing,' but prefers to adduce the name Astvatorota, Bartholomae, col. 215, the same elements in reverse order, ' with body subject to justice.'

61a Herodotus, iii. 66 .

62 Dittenberger, O.G.I. 225, 1. 36.

${ }^{63} \mathrm{Ib} .238,1$. 1. See his notes on both passages, mostly founded on Haussoullier, Rev. de Philologie, xxv. (1901), p. 6 sqq.; cf. W. H. Buckler, 'Greek Inscr. from Sardes,' in A.J.A. xvi. (1912), p. 69. A. Corvatta, 'Divisione Amministrativa dell' Impero dei Seleucidi,' Rendi conti d. r. Acc. d. Lincei, x. (1901), p. 149, does not seem to recognise them.

of O.G.I. 532, 1. 38.

65 Though for these I had recourse to F.
Justi, Iranisches Namenbuch, Marburg, 1895, and Chr. Bartholomae, Altiranisches Wörter. buch, Strassburg, 1904; I should not have got far without the help and criticism of Professor J. H. Moulton, D.D., of Didsbury College, Manchester, Professor A. Carnoy, of Louvain, and Mr. E. J. Thomas, of the University Library, Cambridge, and I am much indebted to them. They are not, however, responsible for my errors.

ארשהת Apšatata. 


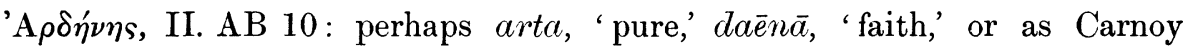
prefers to render, 'conscience,' Bartholomae, col. 665.

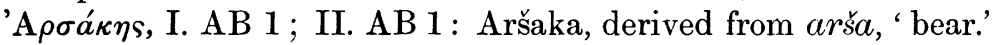

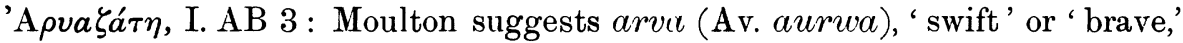
and $\bar{a} z \bar{a} t a$, 'noble,' but says a dvandva name of this kind requires a parallel. Such Carnoy finds in Wahištāzād, 'best-noble,' Justi, p. 340, and perhaps $\check{C} i h r \bar{a} z \bar{a} d$, ' high-noble,' ib. p. 163. Probably not Arya, 'Aryan,' as $v$ was still an $u$, cf. ' $\Upsilon \rho \omega ́ \delta o v=H u r a u d a$ on a coin, Wroth, B.M.C. p. 96. Perhaps divide arva-zāta, Moulton.

'A $\sigma \pi \omega \mu a ́ k \eta s$, II. AB 5 : aspa, ' horse.'

Av́rouá, I. AB 4: perhaps Armenian. Carnoy suggests the superlative of aota, 'cold,' Bartholomae, col. 41, or aota, 'understanding,' Justi, p. 52 ; cf. Aं่

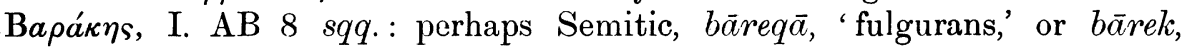

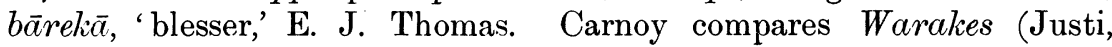
p. 348) or vahrka, ' wolf.'

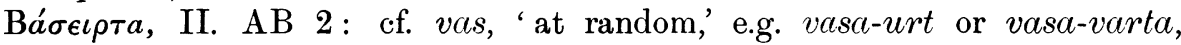
' turning or ruling at random,' Carnoy.

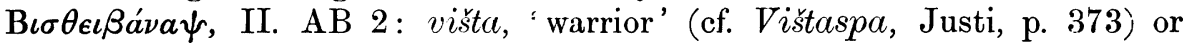
vahišta, 'best.' It might be an altered form of vanovispa, " all blessing,' Bartholomae, col. 1354, Carnoy.

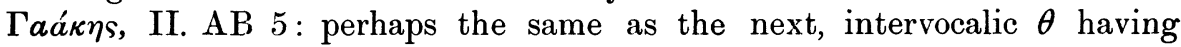
become $h ;{ }^{66}$ cf. Hübschmann's derivation of Phrahates from Fradāta below.

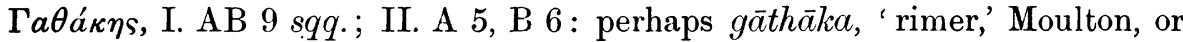
' living after Gathic rule,' Carnoy ; or from gaēth $\bar{a}$, 'farm,' hence ' householder,' E. J. Thomas.

Гєрікүя, II. A 12, B 17 : perhaps gairika, 'living in mountains,' Carnoy.

$\Delta a \rho \gamma \eta \nu \eta^{\prime}$, II. A. 13, B 11 : O. Pers. darga, 'long,' Skt. āna, 'mouth,' cf. $\pi \rho \eta \nu \eta^{\prime}$ (?), Moulton. Perhaps 'holding something.'

$\Delta \eta^{\prime} \eta$ s, II. AB 5: (used as a genitive, possibly from fem. nom. $\Delta \eta^{\prime} \nu \eta^{66 a}$ ): daènā, Pahlavi dèn, ' faith.'

$\Delta \eta \nu o^{\prime} \beta a \zeta o s$, I. B. 30 : Daènavvazah, 'advancing the faith', is a name in the

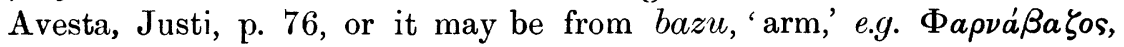
Justi, p. 92. (Moulton does not allow that $\delta \eta \nu o-$ could be from $\operatorname{dae} n \bar{a}$.

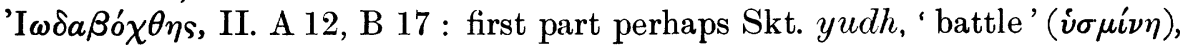

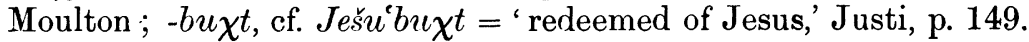

$\mathrm{K} \lambda \epsilon о \pi a ́ \tau \rho a$, II. AB 2: the only Greek name in the documents.

Maıфóp’óns, I. A 8, B 9 : probably Semitic, məphōrrā̌s, 'separated'; for the termination cf.

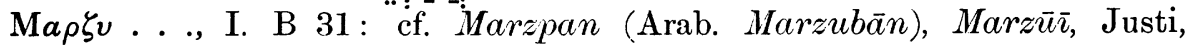
pp. 197, 198.

${ }^{66} v$. C. Salemann, Geiger u. Kuhn, Grundr. d. Iran. Phil. I. i. p. 261. 66a Not very likely hecause aủ $\hat{\varphi} \hat{\varphi}$ and $a \dot{\tau} \tau \dot{\nu} \nu$ follow, but cf. P. Lips. 2, 1. 10. 


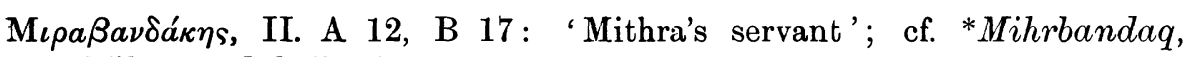
Mihrevandak, Justi, pp. 205, 214.

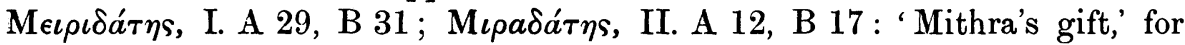
form see below.

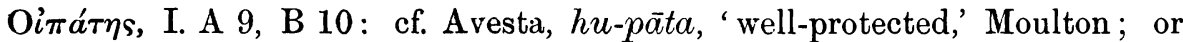

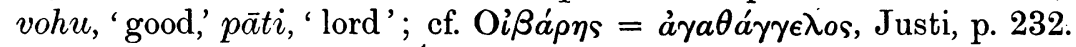

'O

'O 'O

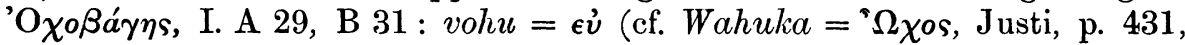

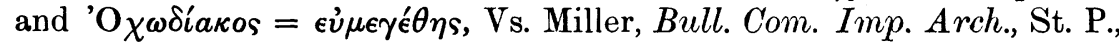
xlvii. p. 87) and baga, 'god.'

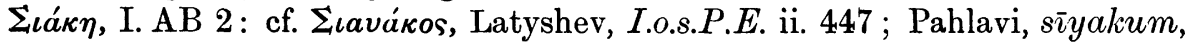
thirty-first, E. J. Thomas.

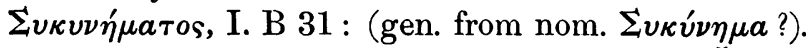

$\Sigma \omega \beta \eta ́ v \eta s$, I. A 8, B 9 : perhaps Semitic; ef. Śebna, Isaiah xxxvi. 3, LXX.

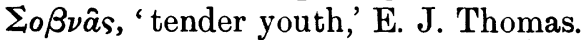

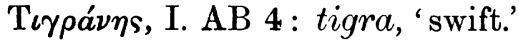

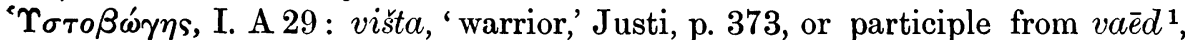
'knowing,' or vaedd', 'having found' (Bartholomae, cols. 1314, 1318), $b \bar{a} g a$, 'lot'; $\bar{a}$ is often pronounced $\bar{o}$ in Persian and Ossetic. Carnoy says 'vahištobäga, with best lot or fate.'

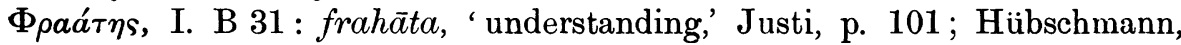

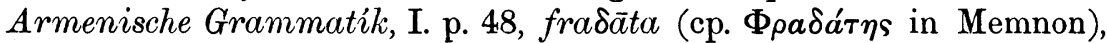
'furthered'; hāta, perf. pass. part. of han occurs in Gāthic = 'meritus,' so frahäta would be 'promeritus,' Moulton.

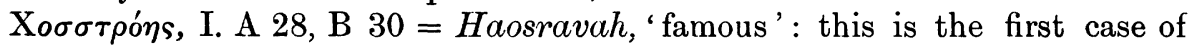

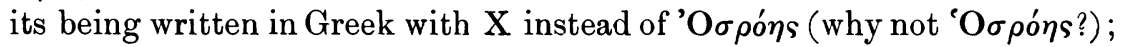
v. Justi, s.v. Husrawainh, p. 134.

The general character of these names is clearly Iranian : the only exceptions are those of the conveyors in I., Baraces and Sobenes with their father Maiphorres, and the queens in II., Cleopatra the Greek, and Olennieire, Baseirta, and Bistheibanaps of which the explanations cannot be called convincing. Did Phrahates IV. seek his wives among the mixed peoples who were pressing upon his eastern frontier as well as from Greece and Italy?

Of these Iranian names some we must leave to students of Iranian, others are familiar to us all, Chosstroes, Tigranes, Phrahates, Arsaces, Miradates. The particular form in which this last and its cognate Mirabandaces appear offers as much interest as almost any point that arises from the study of the documents. They are the first recorded instances of a sound change which most characteristically marks off Middle Persian from Avestic and Old Persian, the change of $\theta r$ to $h r$ between vowels. ${ }^{67}$

${ }^{67}$ v. C. Salemann, in Geiger u. Kuhn, Grundr. d. Iran. Phil. I. i. p. 261. 
That change would not have been expressed in writing unless it was quite general in pronunciation; tradition kept the form Mithradates in use for centuries, but the first example hitherto known of the name in its later form was given by Tacitus ${ }^{68}$ who mentions Meherdates as a candidate for the Parthian throne in A.D. 47, 135 years later than I. This fact has naturally aroused the attention of Professor Moulton as it leaves so much the less time for the completion of the sound changes which took place subsequent to Zoroaster but within the Old Persian period, and strengthens the argument for the prophet's early date. ${ }^{69}$ Of the $i$ vowel in the middle instead of $a$, there are earlier examples extant. ${ }^{70}$

As to the rendering of Iranian sounds: $\epsilon \iota$ evidently sounded like $\iota$, but it is not probable that ou or $v$ had come down to the same, nor does it seem to me as if $\beta$ was yet sounding as $v$. Iranian $h$ is left unexpressed, unless $\chi$ represents it in 'O $\chi \circ \beta a ́ \gamma \eta s ; a$ represents the dull vowel $\partial$ as well as $\bar{\alpha}$ and $\breve{a}$. There is, as it seems, some inconsistency in the rendering of $v$, but philolngists expect too much consistency and shut their eyes to the way in which we render, e.g., Russian names. ${ }^{11}$ Greek could of course do nothing with $\check{\text {. }} \quad$ As the names shew Middle Iranian forms, probably Document III. (if Iranian at all) is the earliest piece of Middle Iranian extant, if only it could be read.

\section{Legal Transactions.}

All these matters of kings and queens, dates and names, were but of very little importance to the people who had our documents written, and they would have been much surprised to find that their transactions, to record which the documents came into being, are now the least interesting part of them. Further, the nature of the transactions is not quite clear.

One reason for this is that we have hardly any material for satisfactory comparison. Dr. Hunt writes 'there is a strong family likeness combined with differences in detail as compared with similar documents from Egypt,' but my search for analogies amid the great mass of Egyptian material has shewn me that the differences are greater than I had supposed at first. To the layman legal documents concerned with more or less similar transactions have all of them what I should call a family likeness, but as we can see that formulae varied in different districts within Egypt, ${ }^{72}$ it is not surprising that our documents should be unlike in detail.

I hoped that the formulae of cuneiform documents would offer some help in reconstituting the intentions of the writers, but Dr. L. W. King

68 Ann. xi. 10.

69 J. H. Moulton, Early Zoroastrianism, 1914 , p. 233, and addenda facing p. xviii.

70 Dittenberger, O.G.I. 345 (в. C. $92 / 1$ ), 1. 28 and note $a d$ loc.

71 For a similar problem, cf. H. Kern,

'Zur Gesch. d. Ausspr. des Griechischen : Widergabe Indischer Wörter bei gr. Autoren,'
E $\Lambda A$ A, Leiden, 1889. He shows that the traditional Greek accentuation does not repre-

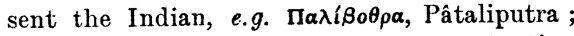

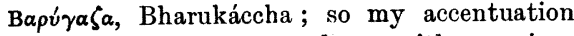
of these names is in accordance with meaningless custom.

72 Mitteis, Grundzüge d. Papyruskunde, II. i. p. 76, n. 2 . 
assures me that there is nothing specifically Babylonian about ours. The deeds published by Professor A. T. Clay (op. cit.) are not far off in point of time but offer no analogies save what are inherent in the nature of the case: I do cite one or two resemblances in detail, but do not insist upon them. Our documents must therefore serve to illustrate each other even though the transactions recorded are not exactly similar: I have said that I believe them to refer to the same property, but that Dr. Hunt is not inclined to agree.

We want all the illustration we can get because both documents are most carelessly put together. It cannot be said that the scriveners were ignorant of Greek: the writer of I. knew his business quite well, that of II. might have made less difficulties for us if he had not been so much at home in Greek writing that he hardly stayed to form the letters. But they seem in both cases to have transcribed a rough copy full of badly indicated insertions and erasures ${ }^{73}$ and probably made up of phrases drawn from older deeds and not sufficiently adapted to the grammatical requirements of the case. Hence omissions, repetitions and anacolutha which leave us in actual doubt as to the intentions of the contracting parties.

As to the form of the documents, the first point is their being executed in duplicate. This device of 'close' and 'patent' versions (often called scriptura interior and scriptura exterior) is very ancient. It is the principle of the Akkadian and Babylonian case-tablets in which the original deed is covered with a fresh layer of clay to receive an abstract of its tenor and the seals of the witnesses. Similar procedure was in use among the Jews: our documents are so well illustrated by a passage in Jeremiah (xxxii. 9-14), pointed out by my sister, that I give it here after the Revised Version. 'And I bought the field that was in Anathoth of Hanamel my uncle's son, and weighed him the money, even seventeen shekels of silver. And I subscribed the deed (lit. writing, סֵפר, $\beta \iota \beta \lambda i o \nu)$, and sealed it, and called witnesses, and weighed him the money in the balances. So I took the deed of the purchase [both that] which was sealed, [according to the law and custom (Marg. or 'containing the terms and conditions'), and that which was open]; and I delivered the deed of the purchase unto Baruch, the son of Neriah, the son of Mahseiah, in the presence of Hanamel mine uncle's son, and in the presence of the witnesses that subscribed the deed of the purchase, before all the Jews that sat in the court of the guard. And I charged Baruch before them saying, Thus saith the LoRD of Hosts, the God of Israel: Take [these deeds,] this deed of the purchase [both that which is sealed] and this

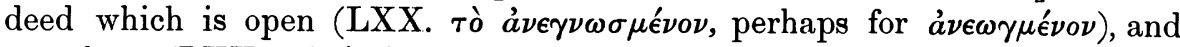
put them (LXX. aútó) in an earthen vessel ; that they may continue many days.' I have enclosed in square brackets the words which are omitted in the LXX.; it looks as if the Greek text had been changed when the practice of making duplicates became unfamiliar.

It had been common enough in Egypt and many examples exist, both

73 e.g. Schubart, Pap. Gr. Bcrol. 13, 13 в.с. 
Demotic and Greek : the oldest Greek contract known, the marriage contract of Heracleides and Demetria (311-310 B.c.) and the deeds concerning Elaphium a few years later, all three from Elephantine, have much the same arrangement as ours: the older practice was to give the deeds into the charge of a $\sigma v \gamma \gamma \rho a \phi o \phi v i \lambda a \xi$ who is named as such in the deed, acknowledges the receipt of it, and sets his seal first among the witnesses, usually six in number. In the passage from Jeremiah, Baruch is the $\sigma v \gamma \gamma \rho a \phi o \phi v i \lambda a \xi$ : he is a private person, not an official, and so likewise in Egypt. ${ }^{74}$

In the Elephantine papyri the mechanical arrangement differs in so far that, the papyrus being very broad, the top version is half cut off from the lower and doubled over with a vertical fold, so the roll is only half as long and makes a stronger packet. The ordinary arrangement is like ours, the papyrus being of a moderate breadth. ${ }^{75}$ The string is supplied by a fibre stripped from the papyrus itself. ${ }^{76}$ The device of a full duplicate is used for very various documents, sales, marriage-contracts, receipts, tax-receipts, declarations, verdicts and oaths, ${ }^{77}$ but the fact that the close version would probably never be seen by mortal eye produced its natural result, either that it was written illegibly (in $P$. Amh. $42 \mathrm{~A}$ the close version is the most cursive document its editors had ever seen) or it becomes reduced to an abstract written above the patent version ; ${ }^{78}$ Wilcken (loc. cit.) shews that from the middle of the third century B.c. practically the same classes of documents are thus shortened down as had been written in full. Moreover, for greater security the execution of the deed is performed before an official and he it is that writes the close version or abstract. In the case of the agoranomus in the Thebaid the office fashion was to use broad papyrus, so the abstract forms a narrow first column ${ }^{79}$ folded down and secured with one official seal. But once deeds were brought to a public office and registered the need for any duplication vanished and the device tended to go out of use. Still it is interesting to note that in the case of the Reinach Papyri, all from the same muniment room, some, dated in the city of Hermupolis where there was an agoranomus, are in the form that he was accustomed to prescribe, while others executed in the little village of Tenis were really delivered to the $\sigma v \gamma \gamma \rho a \phi o \phi v i \lambda \xi^{80}$ It is possible therefore that in Babylonia and Media

74 B.G.U. Sonderheft, 'Elephantine Papyri,' ed. O. Rubensohn, Nos. 1-4, esp. pp. 5-8: W. Schubart, Pap. Gr. Berol. 2, 4a; Wilcken, Archiv f. Papyrusforschung, v. pp. 200-207; New Pal. Soc. ii. 20.

75 See illustrations of $P$. Amh. 42. Pl. VIII.; P. Hibeh, 84a, PI. IX.

76 Ibscher, Arch. f. Pap. v. p. 192.

77 Wilcken, loc. cit. p. 204 ; the latest is 131 B.c.

78 e.g. P. Tebt. i. 105 (103 в.c.), Pl. VIII.

79 P. Lond. 879, 1204, 881, 882, 1206, 1207, 1208, 1209 (iii. Pl. IV.-XI.), 123-88 B.c. : B.G.U. iii. 993 = Schubart, op. cit. 9 .
${ }^{80}$ Wilcken, Arch. f. Pap. iii. p. 523 ; compare P. Rein. 26 (Mitteis, Grundz. II. ii. No. 164) with P. Rein. 14 and 20 (Mitteis, ib. 132, 133): dates 104, 110, and 108 B.c. For duplicate deeds in general see also Mitteis, op. cit. II. i. pp. 77,78 ; P. M. Meyer, Klio, vi. (1906), pp. 452-454; Gerhard, Philologus, lxiii. (1904), pp. 500-503. The last cases of a $\sigma v \gamma \gamma \rho \alpha \phi o \phi v ́ \lambda \alpha \xi$ or something like it are $P$. Tebt. 382 (31 в.c.) and 386 (12 B.c.); by that time the duplicate writing had gone out of use, Wilcken, Arch. $f$. Pap. v. pp. 240, 241 ; Mitteis, op. cit. II. i. p. 54. 
registration had superseded the duplicate execution in the towns (there was a Greek áropavómos at Babylon, v. infra, p. 60 n. 135), but had not penetrated into out-of-the-way places.

Our documents may seem archaic when compared to Egyptian usage of the same date, but are on much the same stage of development as Latin documents, the receipts from Pompeii of the following century, the Dacian tablets of the second century A.D. and also the Tabulae honestae missionis of even the third century, all of which exemplify the same principle, though of course the arrangements for sealing up tablets cannot be quite the same as for parchments.

It has already been mentioned that in the case of both our documents the close and the patent versions do not exactly tally: these divergences have been exhibited in printing the translations. Some are due to carelessness, others to a beginning of the process whereby in Egypt the close version was reduced to a mere abstract, others apparently to an alteration in the terms of the contract arrived at after the close version had been sealed down.

In the case of II. the differences are obviously due to carelessness except that the obligations of the outside guarantor are not put into the close version. In I., besides blunders, one of which affects such an important matter as the actual name of the property concerned, and silence in the close version (like that in II. A) as to the outside sureties, we have a hasty addition in $\mathrm{A}$ of the eatables and dues, which does not quite tally with the corresponding addition to $\mathbf{B}$, and a further provision in $\mathbf{B}$ about the vendor handing over the stock of must, etc., which does not occur in $\mathrm{A}$ at all. It looks as if this addition might have some connexion with the astonishing

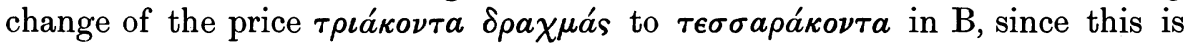
too obvious to be fraudulent. It was perhaps to ratify these changes, which after all concerned things of only momentary importance, not the buyer's permanent right to the land, that the extra witnesses were called in and the definite sureties appointed. It is very strange that the conditions as to irrigation should be more precise in $A$ than in B; no doubt everyone knew at

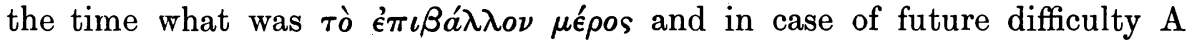
could be referred to.

As regards their general composition our documents, though lacking a $\sigma v \gamma \gamma \rho a \phi \circ \phi v i a \xi$, find their nearest Egyptian counterpart in what Mitteis ${ }^{81}$ calls the syngraphophylax-deed, or, as its real name seems to have been,

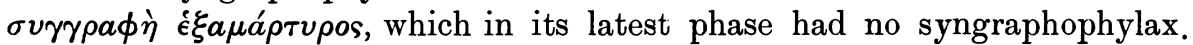
This like ours is a private document, objectively expressed, beginning with the date and ending with the names of the witnesses, and in early times written in full duplicate with one version sealed up by the syngraphophylax and witnesses and with each seal identified by its owner's name. This last detail is absent in our case; the writing at the back of $I$. A cannot have been visible when it was done up and I cannot guess at its purpose. As in the

${ }^{81}$ Grundz. II. i. pp. 53-55.

H.S.-VOL. XXXV. 
very earliest Greek deeds from Egypt, we have no mention of any registration and no duty payable to the state, such as Graeco-Egyptian officialdom soon introduced upon the native model. In these matters our deeds are true to early Greek practice, though registration was independently developed in various Greek states.

Both documents claim to be sales ${ }^{82}$ though perhaps not of fee simple (see below), but the forms are not very like other forms of sale for real property. In Egypt the native law required two separate documents, one the sale including the acknowledgment by the seller that the price has been paid and his warranty of the buyer's title, and the other the release or conveyance of possession from the seller to the buyer. The Greeks adopted the practice of the country and executed two documents, the $\dot{\omega} \nu \eta^{\prime}$ or $\pi \rho \hat{a} \sigma \iota s$, purely

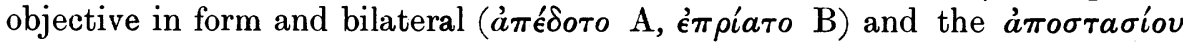

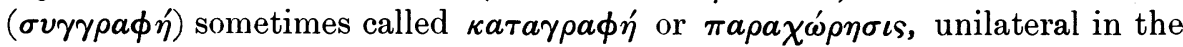
name of the seller who o $\mu o \lambda \sigma \gamma \in \hat{\imath} \dot{a} \phi i \sigma \tau a \sigma \theta a \iota ;{ }^{83}$ this is a transition to the ordinary subjective ó $\mu$ doría. At the end of the Ptolemaic period they began to combine the constituents of the two documents into one and this became usual in Roman times, the form being rather that of the

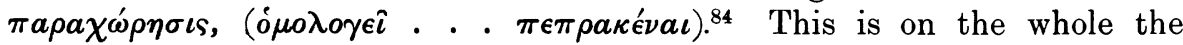

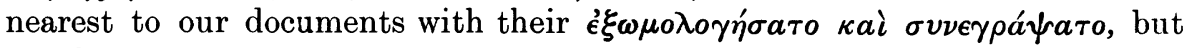
our draftsmen have not been able to keep up the unilateral form and yet get the obligations of both parties in, so that they fall into great difficulties and anacolutha and finally continue in the purely objective form and change about from seller to buyer in the most haphazard fashion. The purely objective form seems to have been the earliest in Greece and so it was in Babylonia, but in the latter the whole arrangement was different, usually beginning with the description of the property followed by the names of the parties, the terms of the agreement, the names of the witnesses and the scribe's subscription, with statement of his fee, and ending up with the date. ${ }^{85}$ Sometimes the name of the vendor stands first. ${ }^{86}$

Before we come to the purport of the documents all possible effort must be made to eliminate the errors of the scribes and to present the texts more or less as they were intended: the interlineations and corrections on each rough copy were evidently so confusedly made that the scribe took them in different ways when writing out the two fair copies; so a comparison of these sometimes offers a chance to divine a consistent text. In other cases he made improvements as he went along, but occasionally the alterations were so carelessly made that we can as it were follow their course.

In I. for instance we can clearly see that ll. A B 8-11 must have run

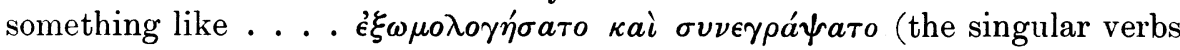

\footnotetext{
82 See M. J. Bry, La Vente dans les Papyrus G'réco-Égyptiens, Paris, 1909, and Mitteis, op. cit. II. i. pp. 167-183.

8: e.g. Mitteis, II. ii. 252 , which has both on one sheet.

84 e.g. P. Lond. 154 (ii. p. 178) Mitteis,

255, 63 A.D., a document which presents us with many small analogies.

${ }^{85}$ e.g. F. E. Peiser, Babylonische Verträge Berlin, 1890 , p. 131 , No. xciv.

${ }^{86}$ A. T. Clay, op. cit. p. 25 , No. 2 (No. 23 ).
} 
are probably taken bodily from another document, but they may imply that one of the brothers, perhaps Baraces who is not the true vendor, is an

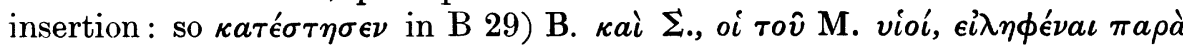

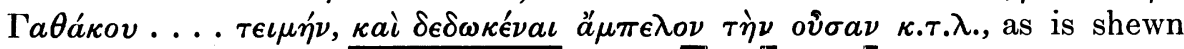

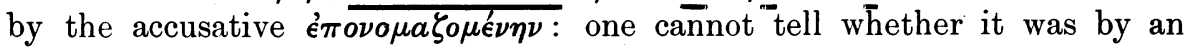
oversight or in an attempt at conciseness that the scribe left out $\kappa a i$

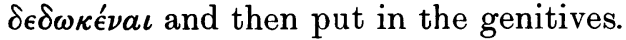

As between Dadbakanras and Ganzace it impossible to judge.

The next two lines 11, 12 are more difficult to restore: it looks as if

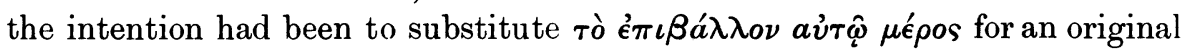

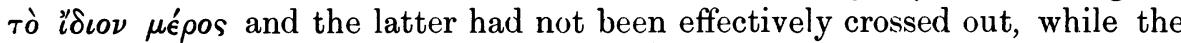
scribe added $\pi a \rho a \grave{\tau} \tau \hat{\omega} \nu \sigma v \nu \kappa \lambda \eta \dot{\eta} \omega \nu$ as he wrote A: so the next words seem

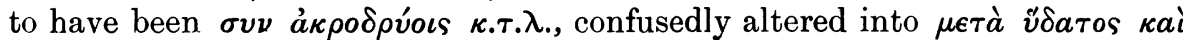

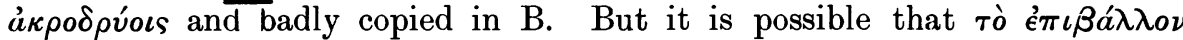

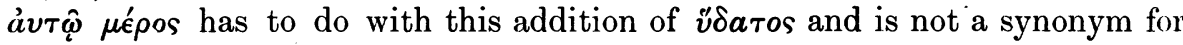

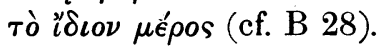

In 1l. 14, 15 the scribe made the phrase in A tò ề $\mu$ épos clearer by substituting $\tau \grave{o} \ddot{\eta} \mu \iota \sigma v$ in $\mathrm{B}$.

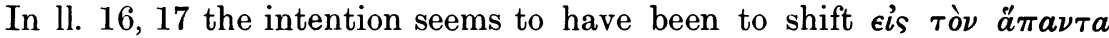

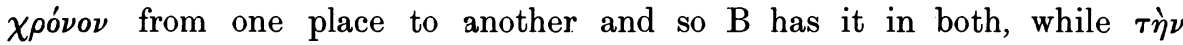

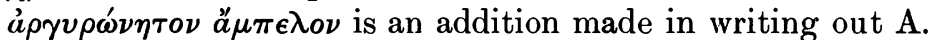

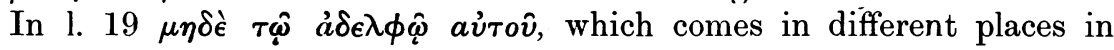
$A$ and $B$, is probably an insertion as it is not quite in common form. The next line and a half seem amplified in writing out $B$.

The differences from line 27 on have been already discussed; they represent a real change in the transaction as registered in the two versions.

The text of II. A and B is fairly straightforward and offers no important divergences until we get to 1 . 9, nor would the subsequent part of A awake much suspicion by itself ; there is only the very harsh plural $\tau \epsilon \lambda \epsilon \in \sigma o v \sigma \iota$

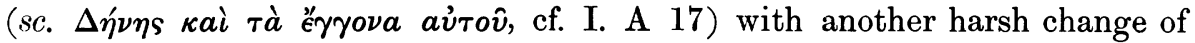
subject in ímé $\sigma \chi \epsilon \tau o$ referring apparently to the vendor, and the nominative 'A $\rho \theta a \sigma \theta a ́ \tau \eta s$, a mere slip. But as it stands in B 9, 10 the sentence about the dues and presents of food has suffered hopeless dislocation, $\kappa \rho \epsilon \iota \theta \hat{\omega} \nu \delta$ v́o has

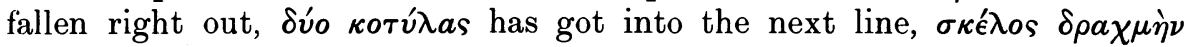
$\mu i a \nu$ comes in a different place, the word $\sigma \kappa e ́ \lambda o s$ being repeated, and finally there is an insertion of $\dot{\epsilon} \mu \beta a ́ \theta \rho o v \delta \rho a \chi \mu \eta^{\prime} \nu$. This confusion makes it impossible to be sure what the writer's intention was, e.g., whether $\kappa a \tau$ '

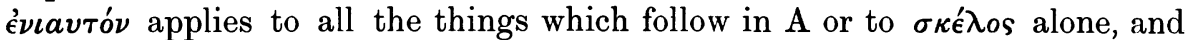
whether $\dot{\epsilon} \mu \beta a^{\prime} \theta \rho o v \delta \rho a \chi \mu \eta^{\prime} \nu$ ought really to come after it. I am inclined to

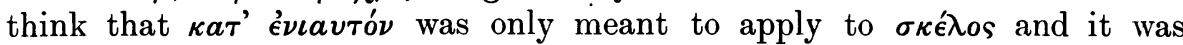

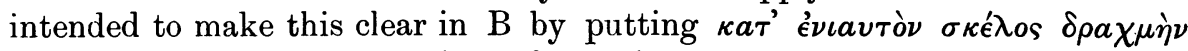
$\mu i^{\prime} a \nu$ last and inserting $\dot{\epsilon}^{\prime} \beta a^{\prime} \theta \rho o v \delta \rho a \chi \mu \eta^{\prime} \nu$ at the beginning, but that it was so badly indicated that confusion resulted. The new clauses in B 10-12 about the outside guarantor have equally miscarried: a measure of the writer's carelessness is seen in $\beta \epsilon \beta a \iota<\omega \sigma \epsilon \iota \nu>$ absolutely unfinished : the next 


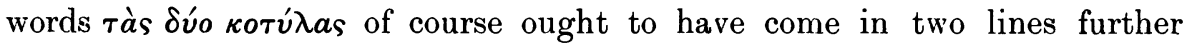

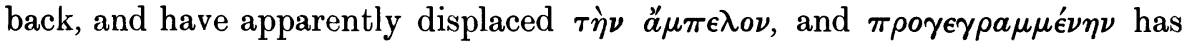
been altered to agree.

Considering the extreme carelessness shewn in B 'A $\rho \theta a \sigma \theta a \dot{\tau} \eta s$ is probably more correct than 'A $\sigma \theta$ át $\eta$ s.

In the next clause the negatives $\mu \eta \delta \epsilon \nu^{\prime}, \mu \eta \delta \epsilon \mu i^{\prime} a$ are strictly speaking quite out of place and there is nothing to account for the infinitives

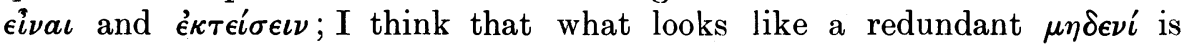
the only word left from a clause something like $\dot{v} \pi \epsilon \sigma_{\chi} \chi o \nu \tau o \quad \delta \dot{\epsilon} \mu \eta \delta \dot{\nu} \nu \tau \hat{\omega} \nu$

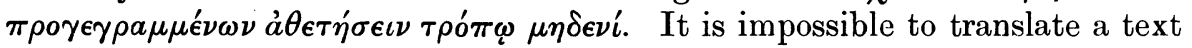
in such a state.

The purport of I., even after such emendations as we can arrive at, is not quite certain. The vineyard Dadbakanras (or Ganzace) is described

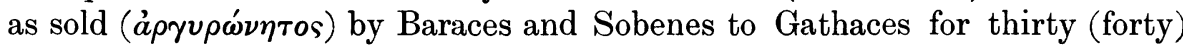
drachmae, but Baraces still retains half of it, and it appears as if it were only Sobenes who parted with his half. ${ }^{87}$ Further, Gathaces and his descendants are under an obligation to pay in full certain burdens on the property, ${ }^{88}$ to look after the vineyard and to keep it properly tied up ("' $\pi a \phi o s$, see below), so he does not get the fee simple even of his own half, and I am not sure that he does not have to keep Baraces's half as well and pay the dues for it, and it is just possible that we have some kind of métayer arrangement.

The general purport of II. is more evident : Aspomaces sells to Gathaces the vineyard Dadbakabag with all its appurtenances for 55 drachmae (of which he ackowledges the receipt) reserving to himself a yearly payment, probably a mere acknowledgment, of one drachma and also a fee of one drachma and certain gifts in kind, but all these may possibly have been rendered yearly. Though the vineyard is spoken of as sold ( $\pi \epsilon \pi \rho a \mu$ $\mu^{\prime} \operatorname{c}_{\nu}, \mathrm{B}$ 13) the transaction is rather of the nature of emphyteusis, the yearly payment shewing that it could not be a conveyance of the fee simple.

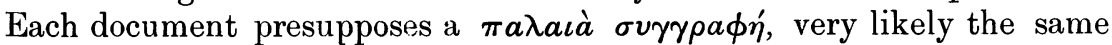
for both, in which full particulars are to be found as to abutments, water-

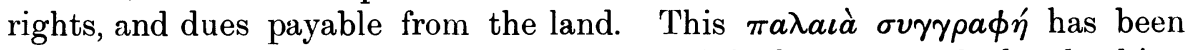
well explained by Mr. Haussoullier as the original grant made by the king to a number of $\sigma \dot{\nu} \nu \kappa \lambda \eta \rho \iota$, perhaps veterans or other servants of the state; this would be the foundation of all subsequent titles and would give the exact dimensions of the various lots, the rent-charges which the state exacted, the mutual rights of the $\sigma u ́ \nu \kappa \lambda \eta \rho o \iota$ and regulations as to the apportionment of the water. ${ }^{89}$

\footnotetext{
87 Dr. Preisigke first pointed this out in a letter to Mr. Bell. We had formerly been inclined to take it as a hereditary lease or emphyteusis.

${ }^{88} \tau \in \lambda \hat{\omega} \nu \tau \epsilon s$ just might be meant to refer not

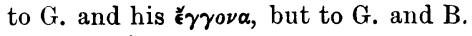

$89 \mathrm{Cf}$. the royal grant to Mnesimachus pre-
}

supposed in the mortgage, A.J.A. 2nd series, xvi. (1912), W. H. Buckler, D. M. Robinson, ' Greek Inscriptions from Sardes I.' The $\pi \alpha \lambda \alpha \iota \grave{\alpha}$ $\sigma v \gamma \gamma \rho \alpha \phi \eta$ is clearly not merely the first of the two deeds which constituted the GraecoEgyptian double sale. 
These being the main lines of explanation, it remains to note a few special points and words in the operative clauses of the documents, the initial protocol and the names of the witnesses having been already discussed.

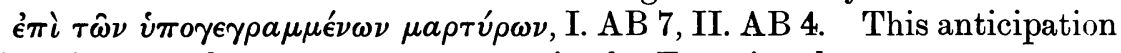
of the witnesses does not seem to come in the Egyptian documents.

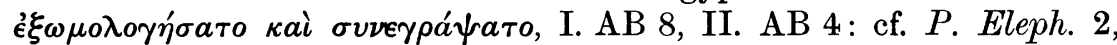
1. 1, entitled $\sigma v \gamma \gamma \rho a \phi \grave{\eta} \kappa a i ~ o ́ \mu o \lambda o \gamma i ́ a,{ }^{90}$ but neither verb is very common in papyri ; in P. Hibeh, i. 30 (d), 1. 18 and Tebt. i. 183, '̇ं of owning up to a debt; but cf. Luke xxii. 6. Judas $\dot{\epsilon} \xi \omega \mu o \lambda{ }^{\prime} \gamma \eta \sigma \epsilon$ to the priests' offer of money: $\sigma v \gamma \gamma \rho a ́ \phi \epsilon \sigma \theta a \iota$ in Grenfell, Rev. Laws, 20, 1. 14 and passim; P. Grenf. ii. 16;P. Tebt. i. 5, ix. 1. 215; P. Lond. 880, 1. 9

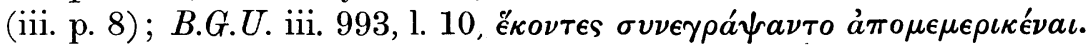

Note in both deeds the absence of the elaborate identification marks usual in Egypt.

$\ddot{a} \mu \pi \epsilon \lambda o s$, I. A 10, B 11, etc., II. A 6, B 7, etc., collective for $\dot{a} \mu \pi \epsilon \lambda \hat{\omega} \nu$, e.g. Grenf. Rev. Laws, col. 36, l. 16 ; P. Tebt. i. 64a, 1. 2 ; B.G.U. i. 33, 1. 4,

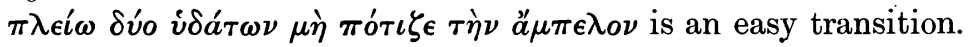

The absence of all description and abutments of the vineyard may be

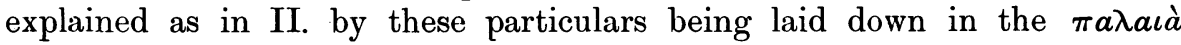
$\sigma v \gamma \gamma \rho a \phi \eta^{\prime}$ : not having to look into the details the scribe even made a mistake in the name, for $\Delta a \delta \beta a \kappa a \nu \rho a ́ s$ and $\Gamma a \nu \zeta a \kappa \eta$ cannot both be right.

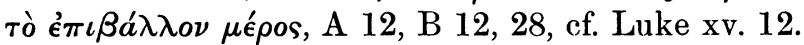

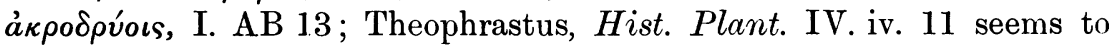
include the vine and olive in $\dot{a} \kappa \rho o ́ \delta \rho v a$, but to exclude them in II. v. 7, where the word means hardier trees such as apples.

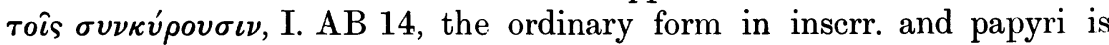
$\sigma v \gamma \kappa v ́ \rho \omega$, not $\sigma v \gamma \kappa v \rho \epsilon ́ \omega, v$. Ditt. O.G.I. 65.

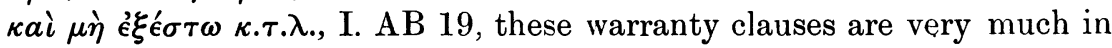
common form. ${ }^{91}$

$\mu \eta \theta \epsilon \nu i$, I. A 20, elsewhere always $\mu \eta \delta \epsilon i ́ s$.

i $\pi \grave{\epsilon} \rho a \dot{v} \tau \hat{\omega} \nu$, I. A 20, 'their agents,' improved in B 20 into $\mu \epsilon[\tau a] \lambda a \mu-$

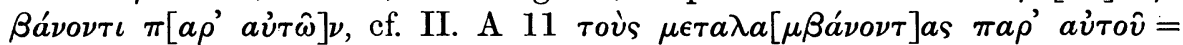
'their successors or those deriving title from them,' common in Polybius, cf. P. Tebt. i. $61 a$, 1. 20, and passim.

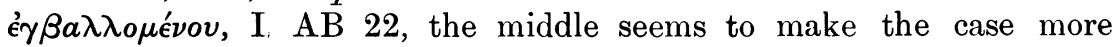

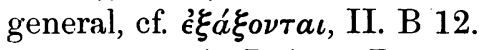

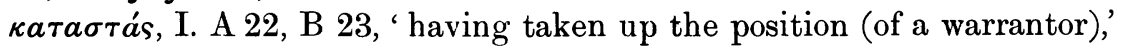

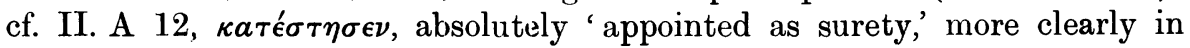

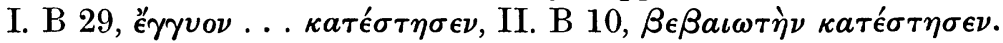

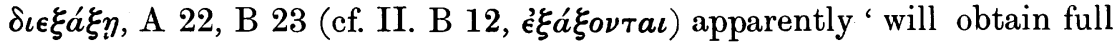
eviction (of the claimant against Gathaces)': true in P. Tebt. i. 5, ix. 1. 219, $\delta \iota \epsilon \xi a ́ \gamma \epsilon \sigma \theta a \iota=$ 'be decided quickly,' $i b .8,1.11$ 'be put out of hand,' cf. Polyb. V. i. 5, and Moulton suggests 'see the matter through': but the use corres-

90 Cf. P. Petr. iii. 21 (b). l. 5 (p. 44), $\sigma v \gamma$ -

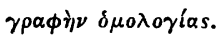

91 e.g. P. Eleph. 3 : Ad. Berger, Strafklauseln in den Papyrusurkunden, passim 


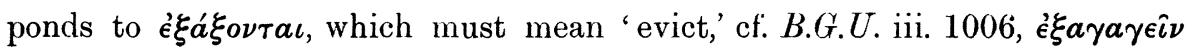

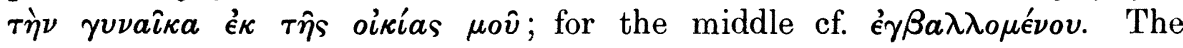
commonest meaning of $\delta \iota \epsilon \xi a ́ \gamma \epsilon \iota \nu$ is 'to carry on someone else's work.'

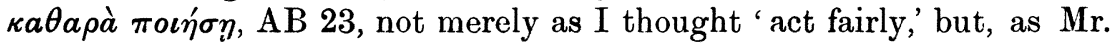
Bell tells me, a technical expression 'acquit,' like the mediaeval 'quietum

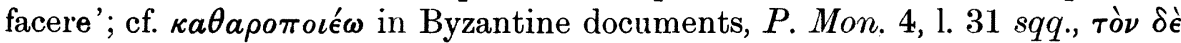

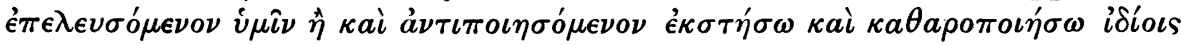

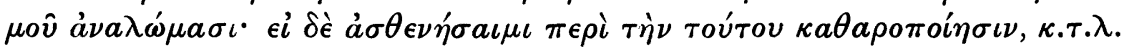

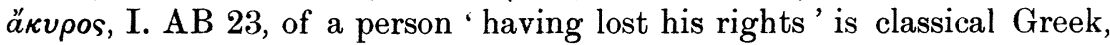
but Moulton tells me he has not met it in Hellenistic, where it is only 'invalid' as in II. B 14. This provision is usual from the earliest times, e.g.

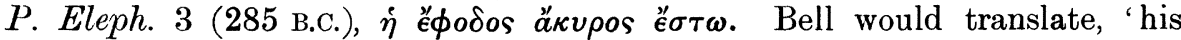

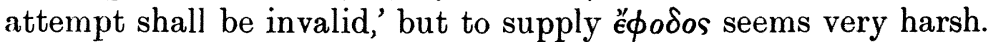

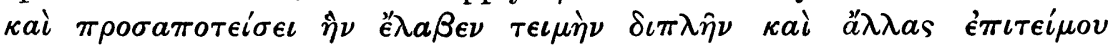

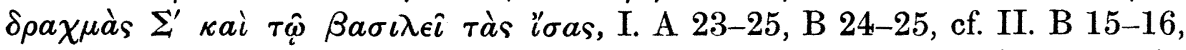

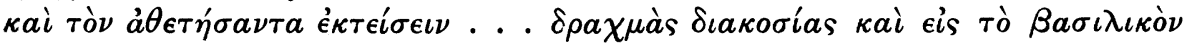

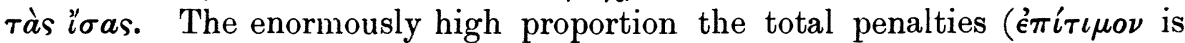
the regular word up to Byzantine times ${ }^{92}$ ) bear to the original price (60 or $80 \mathrm{dr}$. + 200 fine +, probably, 200 to the king : 30 or $40 \mathrm{dr}$.), fifteen or twelvefold, seems to me to be due to the price being merely nominal, a large part of the consideration being the labour that Gathaces was bound to put into the vineyard. It is however noticeable that even in II. we have in all a more than seven-fold penalty. Possibly native custom came in here; in a sale translated by A. T. Clay, ${ }^{92 a}$ the penalty is twelve-fold, all paid to the buyer if she is evicted. The high proportion that the penalty paid to the other party and the penalty paid to the state bear to the price shews also that the object was to make it very disadvantageous to the party wishing to break the bargain; in Roman law the penalty was more moderate, usually the double of the price, and was rather regarded as compensation : but the poena dupli is by no means exclusively Roman; it is found in Babylonian documents, in the laws of Gortyn and in other Greek inscriptions, ${ }^{93}$ but not in Ptolemaic papyri. Berger (p. 128) says it comes in about 100 A.D.: it also occurs in the Palmyrene tariff (137 A.D.). ${ }^{94}$ It is such a natural proportion to fix as a deterrent that one dare not say that it is a Greek element in I.: yet it does look like a proportion still holding its place in the text, although now become a trifle in comparison with the enormous penalties beside it.. There is no

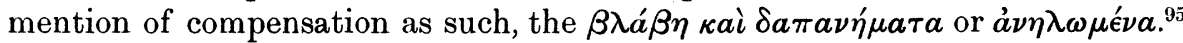
The payment to the king is usual in Ptolemaic papyri, and in those of

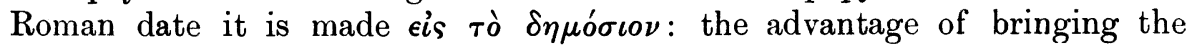
state in to sanction the bargain is obvious and we find the same device in mediaeval deeds.

92 Berger, op. cit. pp. 4-10.

92a op. cit. p. 27, No. 2 (No. 23).

93 Mitteis, Reichsrecht थ. Volksrecht, p. 511 ; Gortyn, Rec. d. Inscr. Jur. Gr. i. p. 372, vi. §38, 1. 42 ; Heraclea (Lucania), ib. p. 202, 11. 109 sqq. ; Athens, ib. p. 242, l. 18 ; Sardes, c. 300 B. c., A.J.A. xvi. p. 65.

94 Ditt. O.G.I. 629, 11. 102, 121.

95 Berger, pp. 26,133 ; A.J.A. loc. cit. p. 80. 
On the whole the nearest approach to our form is in B.G.U.i. 350, Trajan's

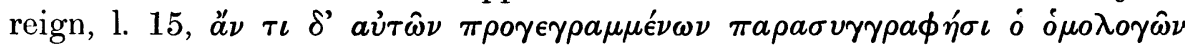

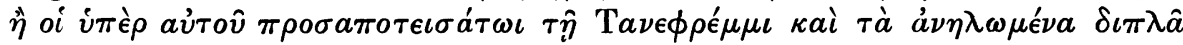

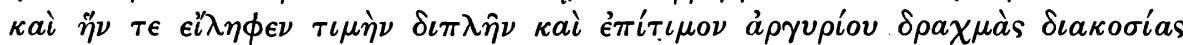

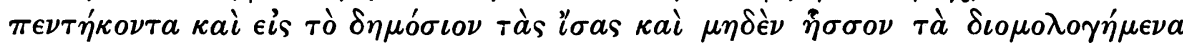

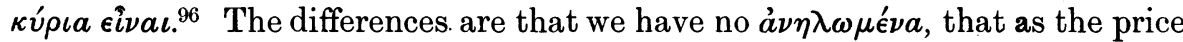
in the Egyptian document was 500 drachmas, the penalties of 250 drachmas each to the purchaser and to the state together only make up the price once, and that the last clause of the document quoted has no counterpart in either I. or II. in which, though no doubt implied, it is not expressed that the contract is still binding after the fine has been incurred and paid. ${ }^{97}$

These same penalties except perhaps the duplum pretii fall on Gathaces in I. if he neglect the vineyard (apparently the whole vineyard)

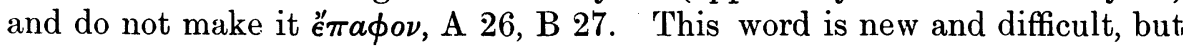

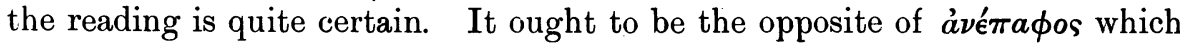
often occurs in sales of land ${ }^{98}$ or in manumissions ${ }^{99}$ and sales of slaves ${ }^{100}$ and evidently means 'subject to no claim.' According to this "̈ $\pi a \phi o s$ would be 'duly subject to claim,' i.e., 'duly acknowledging the original claims of Baraces and Sobenes by rent or service,' but it seems more likely that it is a viticultural term, and Moulton suggests 'tied up,' i.e., the vines tied up to the trees or stakes. Mitteis in his letter says, ' $a \dot{\nu} \in \operatorname{\pi } \pi \phi o s . .$. heist unberührt,

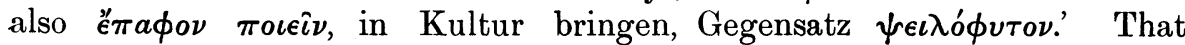
would be giving a meaning of manus iniectio in a very literal sense; whatever the exact meaning, Gathaces has to work the vineyard properly : that this is a strange provision in what purports to be a sale has been already remarked, but if a man lets another in to share a vineyard it is essential to him that his new partner work. Apart from Baraces it is probable that the $\sigma \dot{v} \nu \kappa \lambda \eta \rho \iota^{-}$. who shared the water had an interest in the vineyard being properly kept up.

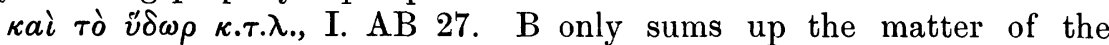

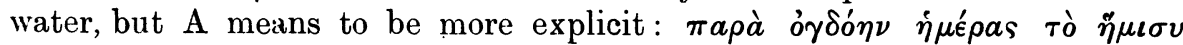

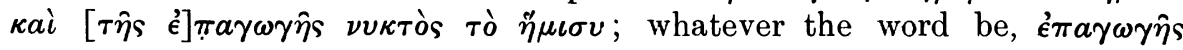

96 Berger, p. 128. C.P.R. 220, is very similar.

97 Berger, p. 82.

98 e.g. Mitteis, Grundz. II. ii. 253, l. 12 ; C.P.R. 220, 1. 11.

${ }^{99}$ e.g. I.o.s.P.E. ii. 54, 1. 12 ; 400, 1. 11 , Panticapaeum and Phanagoria, corresponding to

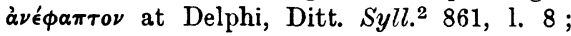
$862,1.11$.

${ }^{000}$ e.g. B.G.U. i. 193 II. 1. 19 , iii. 987, l. 9 (Mitteis, 268, 269) : in these, and in e.g. P. Lond. 251 (ii. p. 317), 1. 15 ; B.G.U. iii. 887 , we have slaves warranted free of $\dot{\epsilon} \pi \alpha \phi \dot{\eta}$; Mitteis, P. Lips. 4, 1. 20, proposes 'leprosy' as its meaning since it always goes with iepà vóros and the like ; cf. his summary, Grundz. II. i. p. 194, n. 2. In a Strassburg pap. (Preisigke, Arch. f. Fap. iii. p. $419,1.30$ ) this is very clear, but the document is 6 th cent. and verbose. Berger, op. cit. p. 140 , n. 4, makes it equal manus iniectio following Kübler, Zt. d. SavignyStiftung (Rom.), xxix. (1908), p. 474-479, in spite of a medical reply by Siidhoff, $i b$. xxx. (1909), p. 406-409. Mitteis, loc. cit., remarks

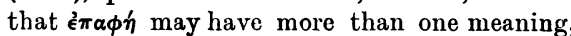
and our document goes to confirm this. Heerwerden s.v. proposes 'madness due to demoniacal possession,' as he thinks no one could fail to spot leprosy, but Südhoff says the early stages may well be overlooked. 
or $\kappa a \tau a \gamma \omega \gamma \hat{\eta} s$, it must be a 'letting in of the water:' What are we

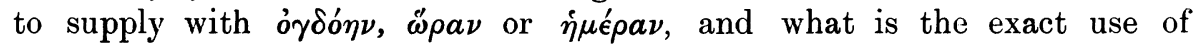

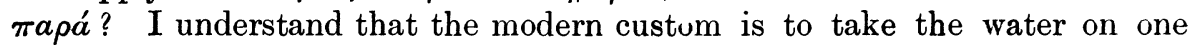
day of the week, so suggest that $\dot{\eta} \mu \dot{c}^{\prime} \rho \nu$ is to be understood, perhaps the following $\dot{\eta} \mu$ épas crowded it out: the meaning would be every eighth, or

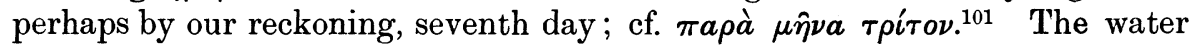
probably came from a kanat, a stream conducted underground to save it from evaporation. The vineyard got a turn at the water every eighth day apparently for twenty-four hours, and Baraces was to share the turn fairly

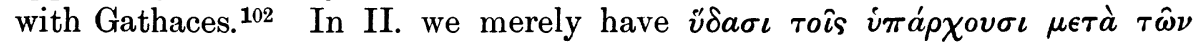
$\sigma \nu \nu \kappa \lambda \eta \dot{\rho} \rho \nu$.

I. A 28, 29 mentions three witnesses Chosstroes, Apaces, and Miridates : in B 30, 31 the witnesses are Denobazus, Miridates, Phrahates and Marzu ... while Chosstroes and Apaces are taken out of the class of witnesses by being

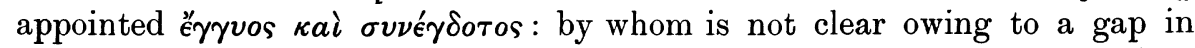

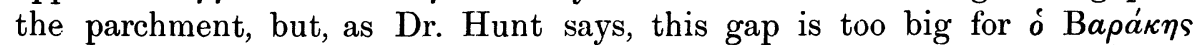

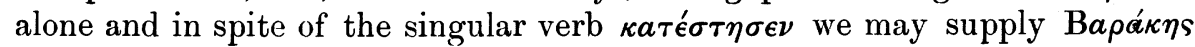
$\kappa a i \Sigma \omega \beta \eta \dot{\nu \eta}$ : it is just conceivable that, as the contract is no ordinary sale but involves the buyer as well as the seller in future obligations, buyer and seller joined in naming the sureties or each named one for himself, so that

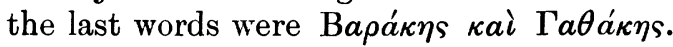

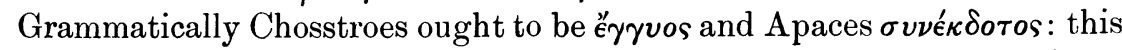

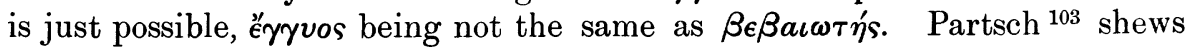
that the latter is only the guarantor of the buyer's title, whereas the former is any sort of surety: in this case he might be surety that Gathaces would fulfil his obligations: $\sigma v \nu$ ć $\gamma \delta o \tau o s$ is apparently a new word and its meaning accordingly uncertain. A bride is called $\dot{\eta}$ é $\gamma \delta o \tau o s,{ }^{104}$ 'given away': if our word is meant as a passive it must mean 'put forward (by the vendor) with himself.' But it is quite likely, as Professor Deissmann suggests, that $\sigma \nu \nu \epsilon \gamma \delta \delta^{\prime} \tau \eta \nu$ is meant: $\epsilon^{\prime} \kappa \delta i \delta \omega \mu \iota$ or $\dot{\epsilon} \kappa \delta i \delta o \mu a \iota$ is used of the Aussteller, the man who executes a document, ${ }^{105}$ also of the lessor in the parable of the vineyard, ${ }^{106}$ and the $\sigma \nu \nu \epsilon \kappa \delta$ '́ $\eta$ s would be the man who joined with the vendor in executing a sale and acted as warrantor, or else the co-lessor $=\sigma v \mu \beta \epsilon \beta a \iota \omega \tau \eta^{\prime}{ }^{107}$ or $\beta \epsilon \beta a \iota \omega \tau \eta \dot{s}$ : but it is more likely that the intention

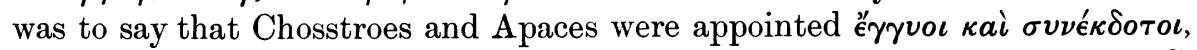

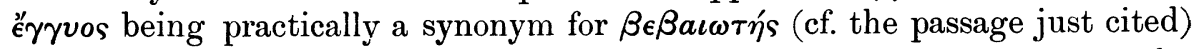
and $\sigma v \nu \boldsymbol{y}^{\prime} \delta \delta$ otos much the same thing: the $\beta \epsilon \beta a \iota \omega \tau \eta \dot{s}$ s is often a person who

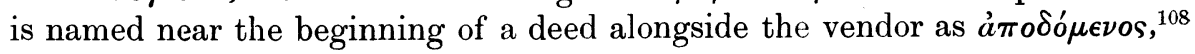

101 Aristot. H.A. VII. ii. 1.

102 The Reverend H. E. Fitzherbert, out of his practical experience of irrigation, approves this view ; ef. Col. P. M. Sykes, History of Persia, ii. p. 495, 'Each villager receives water' every tenth day for about six or seven hours' from the kanat; G. N. Curzon, Persia, i. p. 115 n. ; Polybius, X. xxv. 2.

103 Gr. Eürgschaftsrecht, i. (1909), pp. 340 sqq.
104 Grenfell, Erotic Fragment, 1. 7.

105 Heerwerden cites P. Flor. 95, 1. 15,

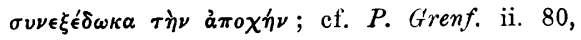
l. $18 ; 81,1.18$.

In6 Matt. xxi. 33.

107 P. Lips. i. 4, 1. 6, cf. 11. 13, 34 : є̇ं $\gamma v \hat{\omega} \mu \alpha_{L}$

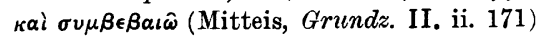

108 Delphi, v. Partsch, op. cit. p. 350, n. 2. 


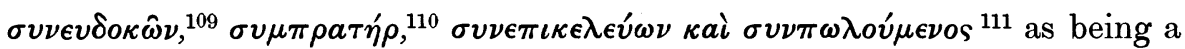
near kinsman with a claim to the property, whose warranty would be of special value. This seems to me ${ }^{112}$ quite a different thing from the old use of calling him actually $\pi \rho \circ \pi \omega \lambda \eta \tau \eta^{\prime}, \pi \rho \circ a \pi \delta^{\prime} \sigma_{\tau} a s$ and even $\pi \rho a \tau \eta \rho^{113}$ which meant that he was originally a kind of deputy seller with all the responsibility of the sale. The important thing is that our documents agree with Greek usage against Graeco-Egyptian. Egyptian law not requiring a warrantor in a sale, the Greek warranty formulas were reduced to an absurdity,

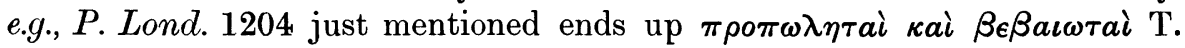

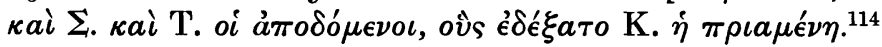

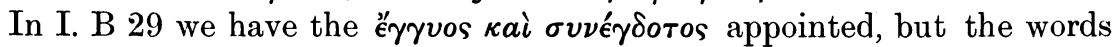
have to speak for themselves. In II. A 12 the appointment of Arthasthates is mentioned, but it is only in B 11-16 that any attempt is made to define the responsibilities of the $\beta \epsilon \beta a \iota \omega \tau \eta$ ' : these are not quite in common form and as the text is very careless it is hard to know what to make of them. In lines 11, 12 we learn that he came in person and promised to guarantee ' the aforesaid two cotylae.' I think it is almost certain that this is a mistake, but I am not sure what ought to stand instead. The guarantor is generally only concerned with the vendor doing his share of the bargain, i.e. giving the

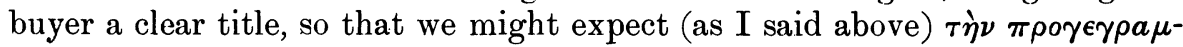
$\mu \epsilon^{\prime} \nu \eta \nu \stackrel{a}{\prime} \mu \pi \epsilon \lambda o \nu$ : but the way in which he is coupled with the vendor in the next clause makes me wonder whether here he is not supporting the credit

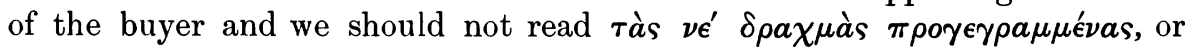
conceivably, if $\kappa a \tau$ ' évıavтó $\nu$ applies to all the payments and gifts following, he may have meant the due future payment of these. The ordinary warranty on the part of the seller and of the guarantor as against any claims to the vineyard is expressed in 11. 12-16.115

The carelessly written addition at the end of I. A has perished in two critical points: the last three lines of B make things a good deal clearer, but they too have suffered and the interlinear additions are illegible. In a way they correspond to II. A B 9, 10, but here again the text is confused.

I. B 32-34 is on the whole the most hopeful. The buyer gives the vendor in addition to the price one drachma of $\epsilon^{\prime} \nu \beta a \theta \rho o \nu$, some meat, 50

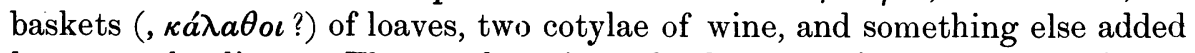
between the lines. The vendor gives the buyer àmò $\lambda \eta \nu[o \hat{v} \tau \grave{o}]$ $\dot{v} \mu a^{116}$

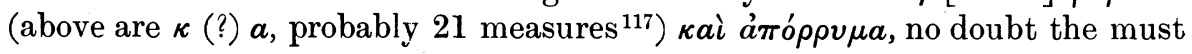

109 ibid. and Ditt. Syll.2 850, 1. 20.

110 Mitteis, Reichsrecht u. Volksr. p. 504 ;

'Lex. Rhet.' ap. Bekker, Anecdota Gr. i. p. 193.

111 P. Lond. 1204 (iii. p. 11) II. 1.17 (Mitteis, Grundz. 152).

112 pace Mitteis and Partsch, loc. cit.

113 Rec. Inscr. Jur. Gr. i. pp. 64 sqq.; Plato, Leges, xi. $915 \mathrm{D}$.

114 For this question of surety and warranty besides Partsch, op. cit., whose Part I. only deals directly with old Greek law and not with papyri, v. Mitteis, Grunz. II. i. pp. 264-270 ; Bry, La Vente, pp. 267-294; and Thalhein, s. v. $\beta \in \beta \alpha i \omega \sigma \iota s$ and $\epsilon^{\gamma} \gamma$ vó $\eta$ in Pauly-Wissowa.

$115 \mathrm{Mr}$. Bell says ' $\xi^{\xi} \xi \alpha^{\prime} \xi o \nu \tau \alpha \iota ~ \kappa . \tau . \lambda$. is only specifying the obligation, not adding something to it, so that I should take $\tau \dot{\eta} \nu \pi \rho o \gamma$. $\varkappa_{\mu \pi \epsilon \lambda o \nu}$ (or $\pi \rho \hat{a} \sigma \iota \nu$ ) as the probable correction.'

116 In C.I.G. 1838 b, 1. 5, Corcyra, it is only rainwater.

117 For the $\kappa$, ef. Tsereteli, Abbrev. in Gr. $M S S .^{2}$, Pl. VI., but it is perhaps more like a $\varsigma^{\prime}$. 
that came off naturally and that which required pressing and was of inferior quality, $\iota \nu \delta a \kappa \ldots . . \nu \zeta \eta \nu$, which I cannot make out, and the squeezed raisins left in the wine-press: the transfer seems to have occurred just at the moment, November, when the wine had been made and as Gathaces was taking over the concern he received these materials just as they were: perhaps the extra ten drachmas put on to the price in B represent the value of these materials. Of this transaction there is no trace in $\mathrm{A}$. But $\mathbf{A}$ gives us another version of his payments to Baraces. The bread seems to agree and the wine and the drachma of ${ }^{\prime} \nu \beta a \theta \rho o \nu$ : the number after the $\kappa \rho \epsilon \hat{\omega} \nu$ looks like $\lambda \epsilon^{\prime}$ in $\mathrm{A}$ and $\epsilon \boldsymbol{\kappa}^{\prime}$ in $\mathrm{B}$ : further in $\mathrm{A}$ we have $\epsilon \lambda o s \boldsymbol{a}^{\prime}$ (?) and $\beta$ ov $s \eta^{\prime}$, which are not represented in B unless perhaps at the end of 1.32 or in the interlineation : $\epsilon$ तos is quite unintelligible, it is certainly not written $\epsilon \lambda a s$ though Hunt and Bell have proposed so to correct it. It is a

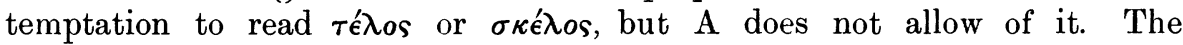
corresponding clauses in II. help in one or two points: they confirm the interpretation $\kappa^{\circ} \beta$ as $\kappa o \tau v ́ \lambda a \varsigma \delta v^{\prime}$, a most extraordinarily small quantity, otherwise we might have thought of $\kappa$ ópo,${ }^{118}$ also the bread, 50 baskets in one case and $\mathbf{2 1}$ in the other, and side by side with this small beer, as Moulton calls it, we have quite clearly five oxen as against the eight in $\mathbf{I}$. But for the oxen these things might be merely materials of a feast to celebrate the bargain, such as was customary in Babylonia and elsewhere, and the two measures of barley in II. A 10 would not have been out of scale, but the oxen are certainly a serious part of the consideration. It is curious that they do not come into I. B unless as an illegible addition.

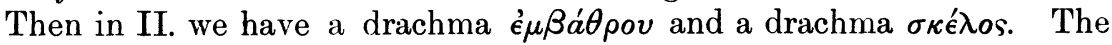
latter is quite unintelligible : it looks as if it might be a new rendering of

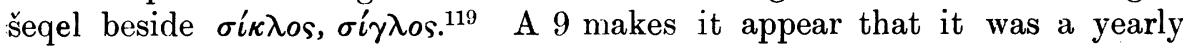
payment, but in B 9 the $\iota^{\prime} \mu \beta a \theta \rho o \nu$ is called yearly. However, it is likely that this is a mistake; perhaps the $\sigma \kappa \kappa^{\prime} \lambda o s$ was a yearly charge on the land either as an acknowledgment or a religious tax. The eै $\nu \beta a \theta \rho o \nu$, I. A 30, B 32, II. B 9, fee of one drachma is new; it seems most probably to have been only paid once and looks as if it were a fee for taking possession, Mommsen's

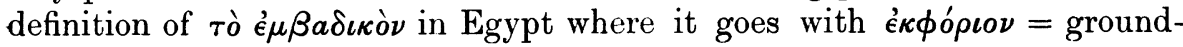
rent ${ }^{120}$ : $\epsilon \mu \beta a \delta i ́ a$ is when a mortgagee forecloses and assumes possession

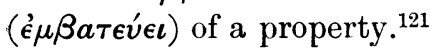

With regard to these extra payments, it seems just worth mentioning that in Babylonian sales there are sums in addition to the purchase-money, e.g. 'Iddinna-Nabu ... has declared that he has bought and pays 1 mina $7 \frac{1}{2}$ šeqels money as his full price and $2 \frac{1}{2}$ šeqels money as at-ri $u$ lu-bar-ri to

118 A measure $=75$ gallons: Josephus, Ant. Jud. XV. ix. 2, Aramaic kor corresponding to Hebrew homer.

$119 \sigma$ oikios represents the vocalism of the construct نִ:

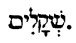

1:0 Wilcken, Gr. Ostraka, 1024, 1237, 1262.

121 'Lex. Rhet.' ap. Bekker, Anecd. Gr. p. 249 ; cf. Mitteis, Grundz. II. i. p. 161, also his 'Geschichte der Erbpacht,' Abhdl. d. sächs. Ges. d. Wiss., xx. No. 4, p. 9. 
the lady of the house he has given them, total 1 mina, 10 šeqels money.' 122 At-ri $u$ lu-bar-ri are explained as 'extra and as a dress,' i.e. a complimentary present making up a round sum. ${ }^{123}$ A little further on (1.31) we come to ‘ 3 šeqel money as a present for sealing,' but this is the scribe's fee.

Lastly, it may he noticed that neither document has any mention of an $\dot{a} \dot{\rho} \rho \dot{\rho} \beta \hat{\omega} \nu$, which is not indeed very common in Graeco-Egyptian sales. ${ }^{124}$

II.

Most of the points in II. have been discussed in connexion with corresponding points in I., but a few remain to be disposed of.

$\psi \epsilon \iota \lambda \phi^{\prime} \phi \tau o \nu, A 6, \mathrm{~B} 7$ : Mitteis in his letter takes this new word as ' bare and uncultivated,' being the opposite to "̈ $\pi a \phi o \nu$, but another possibility is that the opposition is like that in Arist. Pol. I. xi. 4 (1259a), Theophr. Caus. Plant. III. xx. 1, $\psi \iota \lambda \dot{\eta} \gamma \epsilon \omega \rho \gamma i a$, the tillage of land for corn and the like as against $\gamma \epsilon \omega \rho \gamma i a$ ia $\pi \epsilon \phi v \tau \epsilon v \mu \epsilon \in \nu \eta$, tillage for vines or olives, i.e. that the vineyard in question was situated among the corn-crops, not among the other vineyards.'

ộ $\kappa[a i \pi a ́ \rho \omega] \nu$, B 11, a certain restoration by Dr. Hunt on the analogy

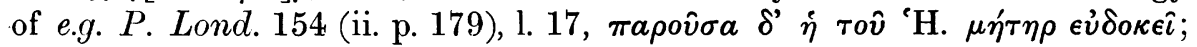
or B.G.U. i. 96, 1. 14, 183, 1. 10 (Mitteis, Grundz. 313), 251, 1. 8, 252, 1. 10 , etc.

$\hat{\epsilon} \mu \pi \circ \imath^{\prime} \theta_{\eta}$, B 13 , regular word for preferring a claim, e.g. P. Lond. 154 (ii. p. 179), 1. 14, B.G.U. i. 13, 1. 13; iii. 987, 1. 11 (Mitteis, Grundz. 255, 265, 269): so A.J.A. xvi. (1912) p. 13, II. l. 2 (Sardes).

$\pi \epsilon \pi \rho a \mu \mu \epsilon{ }^{\prime} \eta \boldsymbol{s}, \mathrm{B} 13$, perhaps the spelling is on the analogy of $\gamma \epsilon \gamma \rho a \mu-$ не́vas.

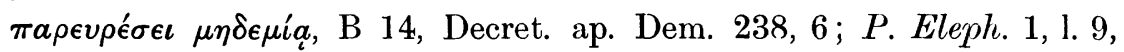
and constantly afterwards.

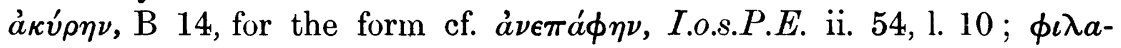
$\delta \dot{\lambda} \lambda \phi \eta \iota$, Ditt. O.G.I. 30, l. 2.

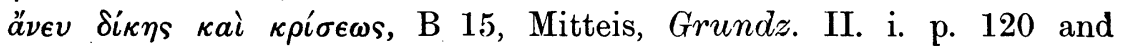
ii. introd. to 62 , regards this clause as mere verbiage; it does often continue

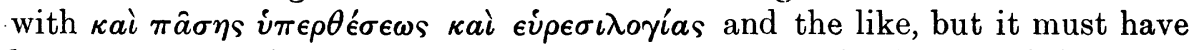
been meant originally to give a summary right to the fine; in Babylonian deeds we have 'the one who shall alter this shall pay, without suit or protest, two minas,' etc. ${ }^{125}$

\section{Hellenism in Media and Mesopotamia.}

But all these things are the merest details. The real interest of these deeds is that they shew the use of Greek law and Greek speech in a region

122 F. E. Peiser, Babylonische Verträge, p. 131, No. xciv. Br. Mus. 84. 2-11. 103, 11. 13-19.

${ }^{123}$ Peiser, Keilinschriftliche Aktenstücke, pp. $81,83,84$, is not quite pleased with the rendering.

124 Bry, op. cit. pp. 104, 118-122 ; Mitteis, Grundz. II. i. pp. 184-186.

125 A. T. Clay, op. cit. p. 29, No. 3 (No. 24). 
wherein we did not dare to hope for it. It is true that Polybius (X. xxiv. 3) speaks of the many Greek cities established in Media by Alexander in order to keep watch upon the barbarians that pertain to it, but this is equally good evidence of the strength of the barbarian element. Of the many Greek cities, we only know of Europus, which was a refoundation of Rhagae, a Heraclea nearby refounded as Achais, a Laodicea and Apamea Rhagiana. ${ }^{126}$ Perhaps Avroman was more nearly connected with the lower course of the Diala, the region of Apolloniatis, with Apollonia and Artemita, ${ }^{127}$ towns which must have had some Greek population.

As to Greek law being used in these parts, the nearest hint of it hitherto has been the existence of the Syro-Roman Law-book, preserved in Syriac, Arabic, and Armenian versions. ${ }^{128}$ According to Mitteis, ${ }^{129}$ in its non-Roman parts this is mainly of Greek origin and contains the remains of the law of the Greek colonists practised by them in their free cities. This Greek nucleus was never dissolved away by the Oriental elements nor quite superseded by Roman law. No doubt it is more an evidence for Hellenistic law in Syria than for such in the Eastern parts of the Seleucid monarchy, but our documents shew that Greek was the law language even here: they mark the last employment of the language, for the third document and the endorsement of I. are in some other tongue. ${ }^{130}$

Apart from its use in law other evidence goes to shew that Greek lost ground very rapidly just about the beginning of the Christian era. ${ }^{131}$ Of the few Greek inscriptions that come from the east of the Euphrates ${ }^{132}$ only that of Gotarzes ${ }^{133}$ is later than this period and it is to be classed with the inscriptions of Ardeshir and Sapor, ${ }^{134}$ and with the coin-legends ${ }^{135}$ as evidence of the prestige rather than the actual use of the Greek tongue.

Older inscriptions come from Babylon ${ }^{136}$ and Susa, ${ }^{137}$ and shew that the Greek colonies in those towns had the regular Greek organization; no doubt

126 Bevan, House of Seleucus, i. p. 264.

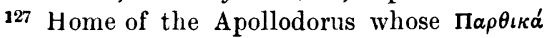
we miss so much.

128 Ed. Bruns-Sachau, 1880.

129 Reichsrecht $u$. Volksrecht, pp. 30 sqq.

130 V. Chapot, 'Les Destinées de l'Hellénisme au delà de l'Euphrate,' Mém. de la Soc. des Antiquaires de France, lxiii. (1904), pp. 207-296, reviews the question very fully: our documents tend to show that he underrates the Greek element.

131 For its use as a lingua franca in lower Chaldaea and eastwards along the coasts, see J. Kennedy, 'The Secret of Kanishka,' ii. J.R.A.S. 1912, pp. 989-1018.

132 See Haussoullier's list in Mélanges Perrot, pp. 158,159 , and $K$ lio, ix. pp. $352-363$.

133 O.G.I. 431.

134 O.G.I. $432-434$.
135 The Greek sovrans naturally struck coins upon Greek standards which had to be tested by Greek weights, e.g. A. Dumont's (Mélanges,

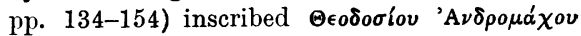
à

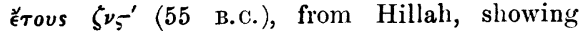
how late Seleucid gold (as there is no Parthian) was still in circulation in Babylon.

136 O.G.I. 253, 254; $r$ and $s$ supra, p. 36 ; J. Oppert, Expéd. Scient. en Mésopotamie (1863) i. p. 168; Dumont's weight; and a disk with

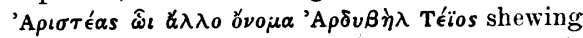
the first stage of Orientalization, ap. Haussoullier, Klio, ix. p. 362.

137 O.G.I. 747 and $\tau \hat{\omega} \nu$ '̇ $\nu$ ồs $\pi[\rho \alpha ́ \gamma \mu \alpha \sigma \iota \nu]$, W. K. Loftus, Travels and Researches in Chaldaea and Susiana, pp. 403, 404 ; Haussoullier, Mél. Perrot, p. 157. 
the same is true of Orchoe (Erech) ${ }^{138}$; the long letter sent by the far Eastern Greek towns, Seleucia ad Tigrim, Apamea ad Seleam, Seleucia ad Mare Erythraeum, Seleucia ad Eulaeum (Susa), and others to Magnesia ad Maeandrum, shews that they had masters of the complimentary style of the third century B.c. ${ }^{139}$ At any rate the great Seleucia ${ }^{140}$ produced a few authors whose names have come down to us, and Charax has Isidore to shew,

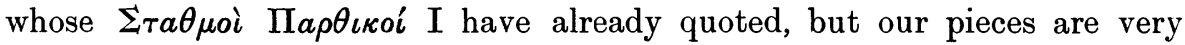
nearly the most easterly examples of continuous Greek known. ${ }^{141}$

When the Parthian kings and their court were brought by their conquest of Susiana and Mesopotamia into close contact with large Greek settlements they certainly put on a veneer of Greek culture. The epithet of $\phi \iota \lambda \epsilon ́ \lambda \lambda \eta \nu$ was the outer symbol of this, but its reasons were political: the Greek cities were the natural allies of the central power. They could furnish the king with troops estranged from the provincial levies and with educated men for engineers and diplomats : he could keep communications open and allow commerce to pass. The enemies of both were the under-kings and satraps whose power rested upon local and racial particularism. It was worth the Parthian king's while to proclaim himself a friend to the Greeks and to try and turn their eyes away from the sinking power of the Seleucids and gain their allegiance for himself. Once masters of the Mesopotamian plain the Arsacids found it the richest part of their empire and made Ctesiphon one of their capitals. Here they could enjoy the lighter side of Greek life and took to themselves Greek concubines or even wives from among the semi-Greek dynasties of Western Asia. Through these Greek speech and Greek customs naturally entered into their lives and it is not surprising that the Bacchae of Euripides should have been playing just when the head of Crassus was brought in. The story aptly illustrates the quality of Parthian philhellenism. It looks, however, as if even this veneer grew thinner after the time of Phrahates IV. The Greeks of Seleucia ad Tigrim and the other Greek settlements were being assimilated by the natives; their towns were less flourishing as the irrigation works fell into decay. The petty dynasties had mostly been extinguished and the Cleopatra of II. is probably the last Greek wife of a Parthian king. Musa was really only a slave girl. The corruption of the coin legends and the gradual introduction of Aramaic letters shew how far things had gone, for conservatism has a strong hold upon coins : English has only got on to one side of our silver and copper and is not yet allowed upon gold. Still some Greek life probably survived until the destruction of Seleucia in 116 A.D.

138 A. T. Clay, op. cit. pp. 16-18, gives 24 Greek names from cuneiform tablets found here; a Greek actually dedicates a slave girl in a native temple. Cf. Oppert-Menant, Documents Juridiques, p. 322, a Diocles, son of Anu-uballiț-su and an Isidore, cf. Anz, Ursprung des Gnosticismus, p. 62.

139 See O.G.I. 231-233.

${ }^{140}$ Chapot, op. cit. pp. 240-246. Oppert's inscription is part of a versified epitaph. Herodicus of Babylon could even write verse to make fun of the Alexandrian textual critics, ap. Athenaeum 222a. We have an Aramaean's name in Greek in C.I.Semit. ii. 72 from Telloh,

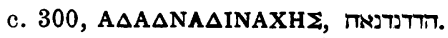

${ }^{141}$ The Book of Tobit is now supposed to have been written in Egypt and perhaps in Aramaic. 
I II III IV

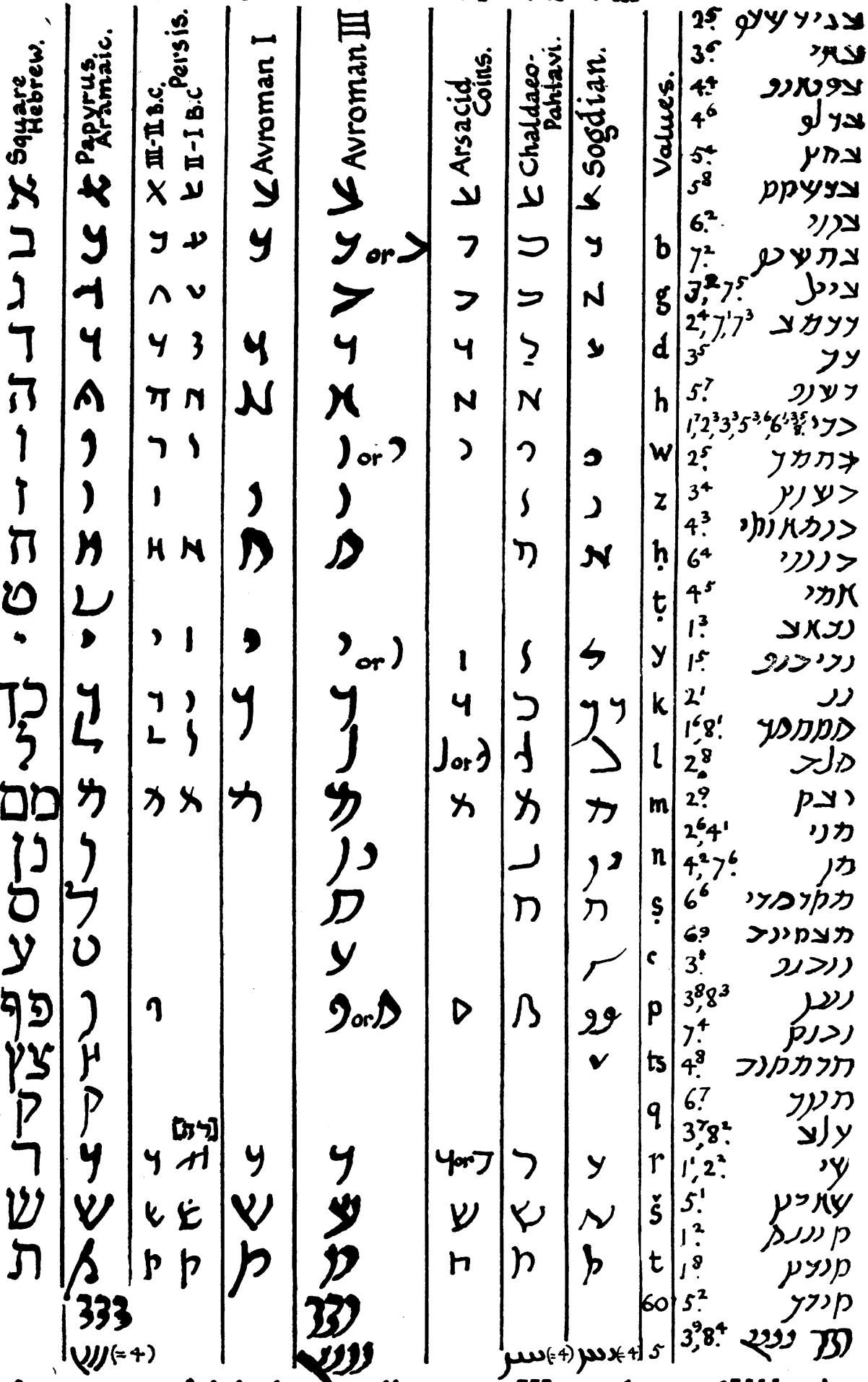

Avroman. Alphabets to illustrate III and List of Words. 
In preparing the paper I read to the Society and now this article I have received help from so many scholars that it is hard for me to give each his due. My first thanks are to Professor Browne who entrusted the documents to me. In the work of deciphering, Professor Burkitt helped me at an early stage. Then Mr. H. I. Bell of the British Museum, to whom I submitted the originals, gave me a whole day's help and advanced things very much, though as we worked together I cannot exactly say which readings are his and which are mine. Since then he has advised me on many points and has read through this article in MS. and set me right in sundry places. Professor A. S. Hunt of Queen's College, Oxford, suggested some most valuable improvements and supplements, while the Reverend H. S. Cronin of Trinity Hall and Mr. B. Haussoullier, Fellow of the Institute of France, pointed out certain inaccuracies in the transcription I circulated. Remarks of Sir Frederic G. Kenyon, Dr. Hunt, and Mr. Bell, threw light on the palaeographical side, while the linguistic and legal interpretation has been advanced by suggestions: from these same scholars, from Mr. W. H. Buckler, Professor A. Deissmann, Mr. Haussoullier, Professor L. Mitteis, Dr. J. H. Moulton, Dr. F. Preisigke, and Professor Rostovtsev; it was a great regret that I could not add Professor U. Wilcken's name to this list. Dr. L. W. King and Canon C. H. W. Johns, Master of St. Catharine's College, Cambridge, have given me much assistance: in matters that involved Assyriology.

My very special thanks are due to Dr. F. J. Allen of St. John's College, Cambridge, for the care and skill which, after the failure of a professional. operator, he gave to photographing the documents.

I cannot close this paper without once more praising the enthusiasm for knowledge which made Dr. Saíd Khán save for European science these memorials of the former use of a European tongue among his Kurdish hills.

\section{APPENDIX.}

The study of Document III. is not Hellenic, but it cannot well be separated from that of the two Greek deeds with which it was found.

Unfortunately, although I have consulted everyone within my reach who might appear likely to help, I have not been successful in identifying the language. I cannot think that it is Aramaic or Dr. Cowley of the Bodleian or Mr. S. A. Cook would have made it out. The natural inference from the Iranian names of the witnesses in the Greek deeds suggests that we have an Iranian tongue. Professor Andreas of Berlin is said to have read it as Iranian and Professor Lidzbarski is quite clear that it is not Aramaic, ${ }^{141 a}$ though containing Aramaic words, whereas Professor Littmann has read the greater part of it as Aramaic ${ }^{141 b}$ : but none of these scholars have told us exactly what they have read, so their successes are no help to us.

Probably the document is in an early form of Pahlavi and as usual in Pahlavi and also in Sogdian there are many 'logograms' or 'cryptograms,' viz. words written as Semitic but read and pronounced as Iranian, just as we pronounce viz. (videlicet) 
'namely.' The only one that I seem to identify is mis, 'from,' which occurs twice $\left(4^{2}, 7^{6}\right)$, but as I know neither any Semitic language nor any Iranian I cannot do anything.

It is however possible to place the script in its position among known alphabets. Table II. shews this clearly. Without claiming much for the values I have assigned to individual letters I have had little difficulty in arranging all the forms present in the document in such a way as to make them correspond to forms that we know from coins minted in Iranian countries; Column III. shews the earlier and the later forms of the letters on the coins ascribed to sub-kings of Persis during the later Seleucid period as set out by Colonel Allotte de la Füye. ${ }^{142}$

The coins of the Arsacids themselves (Col. VI.) do not bear Pahlavi until the time of Volagases I., A.D. 51-77,143 and then but one or two letters ; full legends only come in with Mithradates IV. c. 130 A.D. The coins are unsatisfactory as the letters are very badly formed and we cannot make up the full alphabet. The letters lacking in Sassanian Pahlavi $\bullet, y, y$ and $p\left(t,{ }^{\circ}\right.$, ts, $\left.q\right)$ are naturally absent from the coins, ${ }^{144}$ but we have no certain $i, \pi, 2$ or $D(z, h, n, s)$. I have put beside the early coins the alphabet (Col. II.) of the Aramaic papyri and inscriptions from Egypt dating from the fourth and the third centuries B.c. ${ }^{145}$ The writing on the back of I. (Col. IV.) is noticeably more like these, being more upright and less flowing than that of III. It is most unfortunate that there seems to be no Aramaic writing from Mesopotamia that we can well compare : the dockets on cuneiform tablets are much too old, and the letters on the tile of Hadadnadinakh (p. 61 n. 140) are quite epigraphic. ${ }^{146}$ Col. I. shews the square Hebrew, closely allied and yet familiar : note that the final forms are the more original. On the other side I have put the so-called Chaldaeo-Pahlavi (Col. VII.), ${ }^{147}$ and the alphabet of documents in an early form of Sogdian dating from about the second century A.D. and found by Sir M. A. Stein on the Chinese limes. ${ }^{148}$ It exhibits a different application of Aramaic letters to an Iranian language and is only helpful in one or two cases. I have added a list of words arranged according to their first letter ; they can be identified by the numbers giving the line and the place therein. (The third word in the list is $2^{7}$, not $2^{5}$.)

Such an attempt as mine to assign values to letters according to their form alone without being able to control these values by recognizing the words they make up is something less than tentative : and yet it has seemed worth making. The first result is that except for a very doubtful $y$ only occuring in one word; the letters which are lacking in Pahlavi, $\bullet, y, y$ und $p$ seem to be lacking in ours. ${ }^{149}$ This would argue that we have a similar language. I have some hopes that there is considerable probability in favour of

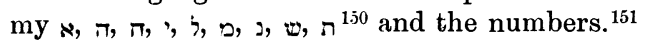

$1+2$ 'Étude sur la Numismatique de la Perside,' B. V. Head, Corolla Numismatica, pp. 63-97, Pl. III.

${ }_{143}$ Wroth, op. cit. p. $272: \triangleright=$ p comes from Markov, Tr. Russ. Arch. Soc. Orient. Sect. vi. 1891, pp. 265-304, 'Unpublished Arsacid Coins,' Pl. III. 22.

${ }^{144}$ Markov, op. cit. p. 298, Pl. IV. 28, gives a coin of Sanabares from which we should get $\kappa$ and $y$, but his alphabet is more Kharosthi. ${ }^{145}$ e.g. C.I.S. ii. 146, 147, and 142 .

${ }^{146}$ The alphabet of 'An Aramaic Inscription from Taxila,' Barnett and Cowley, J.R.A.S. 1915 , p. 34 , is scarcely nearer ours.

147 E. Thomas, J.R.A.S. 1868, pp. 241, 265.

148 J.R.A.S. 1911, pp. 159-166, A. Cowley, 'Another Unknown Language from Eastern 'Turkestan,' as modified by R. Gauthiot, $i b$. pp. 497-507, 'Note sur la Langue et l'Écriture inconnues des Documents Stein-Cowley.' These were pointed out to me by Professor Rapson.

${ }_{119}$ The $y$ may be a $y$ and the last letter in $1^{2}$ may be a $p$. Several words end in what looks like $r$ but $I$ think it is more like $r$ : that is perhaps an argument for Aramaic. In book Pahlavi these letters except $p$ appear only in Semitic words; also $\pi$ coincides with $\pi$ and perhaps one character served for both in our alphabet, setting free for $\square$ and, the second forms I have suggested.

150 Professor L. H. Gray read $1^{6,7,8}$ as QHTHR BŠ QUDČ and $2^{8}$ as MLK, which disagrees with me in nearly every particular. Professor Bartholomae reads this last word as marak, M.Pers. ' number,' and $3^{7}$ as arz, 'worth,' with the numerals following, but I do not feel inclined to give up my and $\zeta$.

151 Cf. the numerals in C.I.S. ii. 146, 147, and Lidzbarski, Handb. d. Nordsemitischen Epigraphik, p. 200, Pl. XLVI. 
Any Aramaic alphabet is sure to have ${ }, 7, \supset(\rceil)$ and $\urcorner$ very much alike; the details are only to be distinguished by the sense, but we have 7 shaped letters enough to represent them. Again, and ; are likely to be indistinguishable and, or , may come very close to them in certain positions. In the other cases we have no evidence to make us lean more on the earlier coin or papyrus forms or on the Arsacid or Chaldaeo-Pahlavi. ${ }^{152}$ Everyone has had hopes of the word $1^{7}$ which occurs no less than nine times; bagi, bani, bari, have been suggested, but it is more likely to be a copula. Dr. Cowley's suggestion that $1^{1,2}$ are שנת, 'year,' followed by a number with a termination is most attractive. One would choose 300 or so, making the date a little later than II., and I seem to see a sign for 3 followed by a kind of $p$ not unlike the hundred in Aramaic, ${ }^{153}$ but I cannot get ARŠaKA MaLkA out of the following words. I cannot resist a guess that $6^{6}$ is a compound of Mithra.

We must be not unmindful that the language may be Kurdish, or something quite unknown : the Iranian proper names spread far beyond the limits of Iranian speech, but we must first of all look to Aramaic and Iranian scholars for help in a problem which transcends the limitations of Hellenists.

Ellis H. Minns.

152 I more and more incline to my second thoughts for $r$ and $\square$.

${ }^{153}$ v. Lidzlarski, loc. cit., better still, Sachau, Aramäische Papyrus und Ostraka aus Elephan. tine, Pl. 52, 1. 11 : Pahlavi hundreds go on the same principle, though the sign is not like this. If this is right the words marked $1^{1}$ and $1^{2}$ in the list must be corrected. שנת is the regular 'logogram' for year in Pahlavi. It would give a only the long form in Col. V. 